\title{
Reforming Campaign Finance Reform: A Review of Voting with Dollars
}

\author{
Richard Briffault $\uparrow$
}

\section{INTRODUCTION}

On March 27, 2002, President George W. Bush signed the Bipartisan Campaign Reform Act of 2002 ("BCRA") into law.' The culmination of a six-year legislative and political struggle, BCRA works the most comprehensive change in federal campaign finance law in nearly three decades. BCRA addresses a broad range of issues, including soft money, issueadvocacy advertising, fundraising on federal property, campaign aetivities of foreign nationals, and penalties for violation of campaign finance laws. Enacted in the face of intense political opposition, BCRA, if it stands up in court, is a significant reform achievement.

Or is it? BCRA closely follows the main lines of campaign finance regulation set out in the Federal Election Campaign Act of 1971 and the Federal Election Campaign Act Amendments of 1974 (collectively "FECA")2: disclosure of campaign contributions and expenditures; limits on individual contributions to candidates, political action committees ("PACs"), and parties; limits on contributions by PACs and parties to candidates; and prohibitions on campaign contributions and expenditures by business eorporations and labor unions. BCRA plugs many of the gaps that emerged in FECA's structure as Federal Election Commission ("FEC") and Supreme Court decisions eroded FECA's provisions, and politicians, interest groups, and donors found new ways of raising and spending campaign money that undermined FECA's requirements, restrictions, and

Copyright $(2003$ California Law Review, Inc. California Law Review, Inc. (CLR) is a California nonprofit corporation. CLR and the authors are solely responsible for the content of their publications.

$\dagger \quad$ Vice Dean and Joseph P. Chamberlain Professor of Legislation, Columbia Law School.

1. Bipartisan Campaign Reform Act of 2002, Pub. L. No. 107-155, 116 Stat. 81 (2002).

2. 2 U.S.C. $\$ 431(2002)$. 
prohibitions. By subjecting soft money ${ }^{3}$ and issue advocacy ${ }^{4}$ to regulation, BCRA essentially restores the status quo ante of campaign finance law of the early 1980s.

This may well be a step forward. FECA's disclosure requirements and limitations on campaign money continued to command public support even as the law was flouted in practice. ${ }^{5}$ Moreover, the evasions and fine legal

3. "Soft money" is a campaign finance term used in contrast with "hard money." "Hard money" describes money raised and spent to aid candidates for federal office or political parties with respect to their federal campaigns, in compliance with the disclosure rules, dollar limitations, source prohibitions, and other FECA requirements, 2 U.S.C. $\S \S$ 43I-55. However, some expenditures that have recognizable benefits for federal candidates are-due to statutory definitions, federal administrative action, or judicial decision - considered beyond the scope of FECA and may be funded with money not subject to FECA's constraints. Such money is called "soft money." For example, a state party's get-outthe-vote drive for federal candidates must be funded with hard money. But if the party mounts the getout-the-vote drive on behalf of the party's entire ticket-federal and state candidates together-it may fund a considerable portion of the cost attributable to the state candidates with soft money. As a result, the party can accept contributions in amounts larger than federal law would pcrmit and accept contributions from entities like business corporations and labor unions otherwise forbidden from making contributions or expenditures in connection with federal elections, and the party can use those funds for activities that aid federal candidates. See generally Richard Briffault, The Political Parties and Campaign Finance Reform, 100 CoLum. L. Rev. 620, 628-31 (2000) (hereinafter Political Parties).

4. "Issue advocacy" is a campaign finance term used in contrast with "express advocacy." Under the Supreme Court's decision in Buckley v. Valeo, only "expenditures for communications that in express terms advocate the election or defeat of a clearly identified candidate" may be subject to regulation. Sec 424 U.S. 1, 44, $79-80$ (1976). As a result, disclosure requirements, contribution restrictions, and expenditure prohibitions apply only to funds used to pay for express advocacy. "Issue advocacy" describes campaign communications that can effectively support or oppose a candidate but, because they avoid the language of express advocacy, are exempt from campaign finance restrictions. For example, a television advertisement that sharply criticizes a candidate's voting record, and then urges the listener to call the advertiser for "more information" but refrains from using words that literally advocate the election or defeat of a candidate, is considered to be issue advocacy and is exempt from federal campaign finance regulation. See generally Richard Briffault, Issue Advocacy: Redrawing the Elections/Politics Line, 77 Tex. L. Rev. 1751 (1999) (hereinafter Issue Advocacy).

5. FECA's source prohibitions and dollar limitations have been significantly eviscerated by the rise of soft money. FECA prohibits corporations and labor unions from making contributions in connection with federal election campaigns. See 2 U.S.C. $\$ 44 \mathrm{lb}(\mathrm{a})$. Prior to BCRA's enactment, the law also limited contributions to candidates to $\$ 1,000$ per election from individual donors and $\$ 5,000$ per election from political committces; contributions to the national committees of the political parties were limited to $\$ 20,000$ per individual per year. See 2 U.S.C. $\$ \$ 441$ a(a)(I)(A), (B), (C). In the 1996 election, however, 390 individuals or organizations (including business eorporations and labor unions) gave $\$ 100,000$ or more to the soft-money accounts of the two major political parties-money that could be used to aid federal candidates. Scc Political Parties, supra note 3, at 631. During the 1999-2000 election cycle, soft-money donations to the two major political parties amounted to $\$ 495$ million, or $40 \%$ of total party fundraising. Of this amount, approximately $\$ 300$ million (or $60 \%$ of total soft money and $25 \%$ of total party fundraising) came from just 800 donors, indicating that the average gift from these top donors was $\$ 375,000$ or wildly in excess of federal contribution limitations. Many large donations came from corporations and unions that are barred from making contributions for federal election purposes. See Richard Briffault, Soft Money Reform and the Constitution, I ELECTION L.J. $343,345-46$ (2002).

The rise of issue advocacy has undermined federal disclosure requirements as well as the limits on corporate and union participation in federal election campaigns. According to a study by the Brennan Center, interest groups spent almost $\$ 42$ million on electioneering issue-advocacy television advertising 
distinctions that gave rise to soft money and issue advocacy make a mockery of campaign finance law and have had a broader, demoralizing effect on campaign finance regulation. ${ }^{6}$

Yet BCRA fails to address the fundamental problem with our campaign finance system: the need for funding sufficient to enable candidates to mount competitive races without rendering them unduly dependent on large donors. In our large and heterogeneous society, it takes a considerable amount of money for candidates and others interested in an election to communicate their views to the voters. "Money buys all the things crucial for a modern election campaign" — broadcast and radio airtime, printing and mailing campaign literature, transportation, office space, dataprocessing equipment and computer time, and the services of campaign professionals. Voters receive most of their information concerning the candidates from advertising funded by candidates, parties, political committees, and other groups. Campaign finance, thus, is crucial for both candidate communication and voter education.

In the United States today, most campaigns are funded by private donations. Although private dollars have been the basis for campaigns since before the start of the Republic, private funding breeds certain pathologies. A handful of wealthy individuals and interest groups play an enormous role-wildly disproportionate to their share of the electorate-in funding our election campaigns. Less than one-tenth of $1 \%$ of the population

in the 2000 federal election campaign. See Craig B. Holman \& Luke P. Mclaughlin, Buying Time 2000: Television AdVertising in the 2000 Federal. Election 15 (2002). These ads were not subject to FECA's provisions requiring the reporting and disclosure of the identities of persons and organizations spending above a relatively low threshold amount conccrning federal candidates. $I d$.

6. The distinction between hard money and soft money is bascd on the determination of the Federal Election Commission ("FEC") that a significant portion of the funds given to state parties and spent to support federal and state candidates togethcr may be treated as beyond the scope of federal law because state candidates benefit from the spending. See FEC Advisory Op. 1978-10 (1978) (finding that a state party could use funds impermissible under FECA to defray the "nonfederal" portion of administrative overhead, voter registration, and voter mobilization cxpenses). The FEC has also held that national party committees can set up accounts for the deposit and disbursement of funds otherwise impermissible under FECA to finance the "nonfederal" portion of a combined fedcral-state expenditure. FEC Advisory Op. 1979-17 (1979). As a result, even the national parties' congressional campaign committees-committees created for the express purpose of aiding House and Senate candidates-have been able to raise and spend "nonfederal" money. In the 1999-2000 election cycle, the four congrcssional campaign committees (Housc and Senate Democrats and House and Senate Republicans) togcther raised and spent in excess of $\$ 325$ million in funds that did not comply with FECA's limitations, prohibitions, and requirements. See FEC, National Party Non-federal Activity Through the Complete Two Year Election Cycle, at http://www.fcc.gov/press/ $05150 \mathrm{lpartyfund} /$ tables/nonfedsumm2000.html. For a critique of the role of the FEC in authorizing soft money, see Project fec, No Bark, No Bite, No Point: The Case for Closing the federal Election Commission and Establishing a New System for Enforcing the Nation's Campaign FinANCE LAWS $81-95$ (2002).

7. Comm'n on Campaign Fin. Reform, Ass'n of the Bar of the City of New York, Dollars and Democracy: A Blueprint for Campaign Finance Reform 84 (2000). 
provides $36 \%$ of all individual donations to candidates. ${ }^{8}$ Nor is this group demographically or politically representative of the rest of the electorate. ${ }^{9}$ Private funding gives the affluent a disproportionate role in election campaigns and is, thus, in tension with the norm of one person, one vote. ${ }^{10}$

Private funding may potentially distort government decision making. When candidates depend on private donations, large donors and prospective donors may obtain special access, and their views and concerns may be given extra weight. This may involve not outright vote buying, but more subtle opportunities to participate more extensively and more effectively in influencing official actions. The Supreme Court has referred to this as "the actuality and appearance of corruption resulting from large individual financial contributions." "I

Private funding also usually fails to produce financially competitive elections. Challengers, newcomers, political outsiders, and those without backing from wealthy constituencies have a harder time raising funds and mounting competitive campaigns. With many donors using their contributions to secure access to elected officials, incumbents or those perceived likely to win do better at raising funds from the relatively small pool of affluent, politically active donors than do their opponents. The built-in advantages of incumbency are, thus, reinforced by the private funding system. $^{12}$

Three regulatory techniques that together form the core of campaign finance law-disclosure of campaign contributions and expenditures,

8. In the I 996 federal eleetion, approximately 235,000 donors, or less than one-tenth of $1 \%$ of the population, contributed $\$ 1,000$ or more, for a total of $\$ 477$ million to eandidates and politieal parties, or $36 \%$ of the total individual contributions in that election. A slightly larger group of 630,000 people-or about one-quarter of $1 \%$ of the population-made contributions of $\$ 200$ or more, for a total of $\$ 597$ million, or $45 \%$ of total individual contributions. See Center for Responsive Politics, The Big Picture: Where the Money Came From in the 1996 Elections, at http:/www.opensecrets.org/pubs/ bigpieture/overview/bpoverview.htm.

9. Id. According to a national survey condueted in 1997 of more than 1,100 donors who gave $\$ 200$ or more to congressional candidates in $1996,46 \%$ of the donors had family incomes of $\$ 250,000$ or more, and $81 \%$ had family incomes of $\$ 100,000$ or more; $95 \%$ were white; $81 \%$ were male; $47 \%$ were over the age of 60 and $87 \%$ were over the age of $45 ; 61 \%$ were in business, law, medieine, or another profession; $44 \%$ had a graduate degree; $51 \%$ described themselves as slightly to extremely conservative (compared with $31 \%$ who described themselves as slightly to extremely liberal); and $48 \%$ described themselves as ranging from "lean Republican" to "strong Republican" (compared with $31 \%$ who deseribed themselves as ranging from "lean Democrat" to "strong Democrat"). See John Green et al., Individuat Congressional Campaign Contributors: Wealthy. Conservative and Reform-Minded ( I998), http://www.opensecrets.org/pubs/donors/donors.htm.

10. Gray v. Sanders, 372 U.S. 368, 381 (1963) ("the conception of political equality from the Deelaration of Independence, to Lincoln's Gettysburg Address, to the Fifteenth, Seventeenth, and Nineteenth Amendments can mean only one thing-one person, cne vote.").

11. Buckley v. Valeo, 424 U.S. 1, 26-27 (1976).

12. See Comm'n on Campaign Fin. Reforn, Ass'n of the Bar of the City of New York, supra note 7, at 65-7 I (2002) (describing large number of financially noncompetitive eongressional clections). 
limits on contributions, and public funding for candidates - have been developed to address the problems of the private funding system.

Disclosure is intended to discourage potentially corrupting contributions and to enable voters to take action at the polling booth against candidates who accept such contributions. ${ }^{13}$ Disclosure, however, does nothing to ensure adequate funding for candidates or to promote electoral competition. Nor is there much evidence that disclosure actually reduces large contributions.

Contribution limits more directly attack the danger of corruption by capping donations at amounts arguably incapable of affecting officeholder decision making, as well as by directly prohibiting contributions from certain sources that are seen as particularly problematic. Contribution limits may also indirectly address the problem of unequal influence over elections by restricting the ability of the wealthy to devote their resources to aiding candidates. But, like disclosure, contribution limits do nothing to help candidates obtain necessary funding or to promote competition. ${ }^{14}$

Public funding is the only reform technique that actually seeks to aid candidates and promote competition. It can increase candidates' resources, help challengers, reduce fundraising burdens, and curb the advantage of wealthy self-funded candidates. By alleviating candidates' dependence on private contributions, public funding also attacks the danger of corruption. ${ }^{15}$ Similarly, by reducing the significance of a small number of large donors, public funding promotes voter equality.

Public funding is the least developed component of campaign finance regulation. In federal elections, public funding is available only for presidential candidates. This program has been underfunded since its inception and is increasingly incapable of adequately financing presidential campaigns. ${ }^{16}$ As a result, candidates may be discouraged from participating in the program, and even candidates who accept public funding continue to pursue private funds for activities that can benefit their campaigns. There

13. Buckley, 424 U.S. at 66-67.

14. Contribution limits can have distressing side effects. They promote evasion, as both candidates and donors look for opportunities for donors to give to organizations (like state political parties or national party soft-money accounts) or activities (like independent spending and issue advoeacy) that are nominally separate from a candidate's campaign but that can benefit that campaign. In an era of high and rapidly rising campaign costs, contribution limits foree candidates to devote considerable time and effort to fundraising. The tension betwcen accelerating - and constitutionally uncontrollable-expenditures and statutorily limited contributions provides an opportunity for individuals and intermediary organizations skilled at raising funds to assume an influential role in the system. The combination of rising cxpenditures and limitcd contributions has also benefited wealthy self-funded candidates, as the Supremc Court has held that their expenditures of personal resources for their own campaigns cannot be treated as contributions subject to limitation. See Buckley, 424 U.S. at 51-54.

15. See id. at 91 .

16. See Richard Briffault, Public Funding and Democratic Elections, 148 U. PA. L. REv. 563, 586 (1999) (hereinafter Public Funding). 
has never been a public-funding program for congressional elections. A number of states and cities ${ }^{17}$ have adopted public-funding programs for some candidates, but most jurisdictions rely on disclosure and contribution limits exclusively. Many of the state public-funding programs are also underfunded, reflecting perhaps a misguided desire to reduce not just the role of private money in polities but the amount of money in elections generally.

BCRA follows the basic structure of federal campaign finance law by focusing largely on disclosure and limits on private money while ignoring the public funding option. Indeed, recognizing that limitations on soft money, unaccompanied by public funding, may sharply reduce the availability of money for campaigns, BCRA raises FECA's limits on hard money. ${ }^{18} \mathrm{BCRA}$ also raises the contribution limits that apply to donations to candidates facing self-funded opponents who contribute large sums to their own campaigns. ${ }^{19}$ The increase in limitations on hard money will make it somewhat easier for candidates to raise money but will do little to address the financial imbalance that favors incumbents over challengers.

At best, BCRA's combination of increases in hard money and restrictions on soft money will limit some of the corrupting effects of the private money system without addressing the need for adequate funding. More negative scenarios suggest that the increase in the hard-money limit will erode the presidential publie-funding system ${ }^{20}$ while the restrictions on soft

17. For a recent assessment of public financing laws in thirteen cities and counties (including New York City, Los Angeles, and San Francisco), see CENTER FOR GOVERNMENTAL STUdies, PUBLIC FINANCING LAWS IN LOCAL JURISDICTIONS, Sept. 25, 2002, http://www.cgs.org.

18. Bipartisan Campaign Reform Act of 2002, Pub. L. No. 107-155, § 307, 116 Stat. 81 (2002) (amending FECA $\S 315$ (a)(1), 2 U.S.C. $\S 441$ (a)); see also $i d$. at $\S 102$ (increasing limits on contributions to state political party committees).

19. Id. at $\$ 304$.

20. BCRA could harm the presidential public-funding program because it increases considerably the limits on hard-money donations without increasing the public grants to candidates. Currently, in presidential primaries, hard-money contributions to candidatcs who participate in the funding program receive a dollar-for-dollar public match, up to $\$ 250$ per contribution, subject to a statutory ceiling on the total public payment per candidate. 26 U.S.C. $\$ 9034$ (2002). BCRA doubles the permissible private donation to a presidential primary candidate from $\$ 1,000$ to $\$ 2,000$, but it does not lift the $\$ 250$ limit on the portion of a private donation that is eligible for a public match, nor does it increase the publicmatching ratio or the spending ceiling for primary elections. Similarly, BCRA does not increase the sizc of the public grant to candidates in the presidential general election. As a result, private funding is now a more attractive alternative to the public grant than it was before BCRA. In 1999-2000, George W. Bush became the first major party contender since the public funding law was enactcd in 1974 to participate successfully in the presidential primarics without public funding. Having raised $\$ 100$ million in hard-money donations at a time when he was not yet the incumbent and the hard-money contribution limit was just $\$ 1,000$, President Bush should easily be able to double that in 2004 to $\$ 200$ million running as the incumbent with a $\$ 2,000$ limit. That is more than double the maximum amount of public money likcly to be available to any Democratie candidate contesting both the primary and general elections in 2004. The growing gap between the contribution limit and public funding may also drive many of the leading Democratic eontenders out of the public-funding system. See Thomas B. Edsall, Privatized Primaries? Some Leading Democrats May Eschew Public Funding in '04, WASH. Post, July 10, 2002, at A6. 
money will make it more difficult for candidates to raise funds or will breed new evasive tactics that undermine BCRA-or both--without addressing the need for adequate funding.

BCRA, thus, is only a partial reform. BCRA's enactment, however, may indicate that campaign finance reform enjoys a new degree of political salience. In their new book, Voting with Dollars: A New Paradigm for Campaign Finance, ${ }^{21}$ Professors Bruce Ackerman and Ian Ayres, both of Yale Law School, seek to take advantage of this opening for reform with a comprehensive and creative approach for financing federal election campaigns. Their proposal has two principal components.

First, sharply departing from the past century of federal campaign finance law and, especially, the last thirty years under FECA, they reject mandatory disclosure of the sources and amounts of campaign contributions. Instead, Ackerman and Ayres promote a regime of anonymous donations in which donors contribute through a blind trust. ${ }^{22}$ Donors would still channel their funds to particular candidates, parties, and political committees, but, under the provisions outlined by Ackerman and Ayres, there would be no way for a donee to be certain that a particular donor had made a large contribution to her. As a result, Ackerman and Ayres contend that donors would lose the ability to use their contributions to leverage access to elected officials or to obtain undue influence over government decisions. Contributions made for the purpose of obtaining access to officeholders would likely decline, and the influence of large donors over elections, as well as over the political process, would likely diminish.

Second, Ackerman and Ayres propose that most of the funding for federal elections come from public grants provided in the form of vouchers given to registered voters who could transfer the vouchers to candidates, parties, and political organizations participating in federal elections. ${ }^{23}$ Ackerman and Ayres have emphasized the voucher aspect of their publicfunding program (in contrast to all cxisting public-funding programs, which consist of public grants directly to qualifying candidates or parties). At least as important is their requirement that roughly two-thirds of all campaign money, with current levels of campaign spending treated as a baseline, consist of public funds. ${ }^{24}$ Again, this proposal differs from most other public-funding programs in assuring that public funding is both adequate for campaign needs and the dominant source of campaign money.

21. Bruce ackerman \& lan Ayres, Voting with Dollars: a New Paradigm for Campaign Finance (2002).

22. See id. at 25-44, 93-110. The anonymous-donation component of their proposal grows out of an earlier plan presented by Professor Ayres and a coauthor, Jeremy Bulow. See generally lan Ayres \& Jeremy Bulow, The Donation Booth: Mandating Donor Anonymity to Disrupt the Market for Political Influence, 50 STAN. L. REv. 837 (1998).

23. See ACKERMAN \& AYres, supra note 21 , at 12-24, 66-92.

24. Id. at $89-90$. 
Yet, Ackerman and Ayres also insist on the importance of some continued role for private funding. ${ }^{25}$

As the title of their book suggests, Ackerman and Ayres link their campaign finance system to the rules governing voting. ${ }^{26}$ Their anonymous-contribution proposal intentionally echoes the role of the secret ballot in preventing vote buying and election day corruption. Their requirement that every voter be given an equal voucher of $\$ 50$ to be used solely to finance federal election eampaigns draws on the constitutional norms of near-universal suffrage and one person, one vote. Ackerman and Ayres also stress how much their program constitutes a dramatic departure from the older, outmoded regulatory approach marked by "rigid command and control" 27 and bureaucratic "centralized campaign subsidies." ${ }^{28}$ They emphasize the decentralized, democratic nature of their program, with "the anonymous donation booth" taking the place of government-mandated contribution restrictions and vouchers eliminating the role of bureaucrats in determining which candidates get public funding and how much they get. In their view, the proposal represents not just some new reform program but a new paradigm for thinking about campaign finance regulation. ${ }^{29}$

This Review Essay considers the central elements of Ackerman and Ayres's reform program and their claim that their package constitutes a new paradigm. Part 1 will address the proposal for anonymous donations. The authors make a powerful case that anonymity is more likely than disclosure to curb the corrupting effects of special-interest donations. But an anonymity system depends upon secrecy being maintained, and it is not clear the authors have demonstrated that it will be. Moreover, seereey will not discourage large contributions motivated by ideological support for the donec rather than the desire to win access to a grateful recipient. Under the Ackerman and Ayres plan, such gifts would continue unchecked. Indeed, they will loom larger than they do today, yet voters would be in the dark about the sources and amounts of such gifts.

Part II considers the public funding proposal-what Ackerman and Ayres call "Patriot money." Some public-funding program is essential for a campaign finance reform worthy of the name, but the most heralded component of the Ackerman and Ayres plan is not public funding per se but a voucher system under which voters transmit public funds to candidates.

Vouchers provide an appealing resolution of two of the central issues inherent in any campaign finance system: determining which candidates receive public funds and how much the funded candidates receive. 
However, vouchers will be less effective than grants to qualifying candidates in accomplishing two of the central purposes of public funding: promoting competitive elections and reducing the burdens of fundraising. Despite the shortcomings of the voucher concept, the central features of the Ackerman and Ayres proposal ought to inform other public funding plans, particularly its provisions for a mix of public and private funds, a high level of funding, and a statutory mechanism assuring that public funds dominate private contributions.

Part Ill considers Ackcrman and Ayres's claim that their proposal constitutes a "new paradigm for campaign finance." The Ackerman and Ayres program is, indeed, admirably creative, thoughtful, and well developed, ${ }^{30}$ but their rhetoric is overblown. They rely considerably on just the kind of outmoded "command and control regulation" they dismiss. ${ }^{31}$ Notwithstanding their denunciations of a centralized bureaucracy, they also give enormous discretion to the FEC to define key regulatory measures and modify central aspects of the Patriot program. ${ }^{32}$

Overstated rhetoric to the contrary notwithstanding, the Ackerman and Ayres proposal is an important one, effectively demonstrating the practical possibilities for significant reform under existing constitutional constraints. The two central elements in their structure-anonymous contributions and vouchers-are innovative and potentially significant for future debates over campaign finance. They merit the considerable attention they surely will receive.

\section{I}

\section{From Disclosure to ANONYMITY}

\section{A. Disclosure}

Mandatory disclosure of the sources and amounts of campaign contributions and expenditures has long been a cornerstone of federal campaign finance law. One of the very first federal campaign finance measures, the Publicity of Political Contributions Act of 1910, required the disclosure of campaign receipts and expenditures in House of Representatives elections. ${ }^{33}$ Disclosure was extended in 1911 to include prenomination activities $^{34}$ and was carried forward by the Federal Corrupt Practices Act of $1925 .{ }^{35}$ Due to drafting defects and the lack of enforcement, these measures

30. One of the strong points of their book is a fully worked-out model statute prepared with the assistance of Yale doctoral student Danton Berubé. See id. at 181-221.

31. See id. at 4.

32. Id. at $86-90$ (discussing the FEC's authorization to change the value of Patriot vouchers).

33. Publicity of Political Contributions Act of 1910, 36 Stat. 822 (1910).

34. 37 Stat. 25-26 (August 19, 1911).

35. Federal Corrupt Practices Act of 1925, 43 Stat. 1070, 1072-73 (1925). The 1925 Act strengthened disclosure by requiring all political committces active in two or more states to file quarterly financial reports listing contributions of $\$ 100$ or more with the Clerk of the House (for House 
had little real effect other than signifying the symbolic importance of disclosure. ${ }^{36}$ FECA finally made disclosure meaningful by spelling out comprehensive and precise requirements and by creating a mechanism for enforcement. ${ }^{37}$ Indeed, the last three decades have witnessed extensive disclosure concerning the sources and amounts of funds contributed to candidates, political parties, and PACs, and by PACs and parties to candidates.

The case for disclosure consists of two mutually reinforcing elements. First, as the Supreme Court observed in Buckley v. Valeo, "disclosure requirements deter actual corruption and avoid the appearance of corruption by exposing large contributions and expenditures to the light of publicity. This exposure may discourage those who would use money for improper purposes either before or after the election." ${ }^{38}$ In other words, on the theory that "sunlight is said to be the best of disinfectants,"39 disclosure may prevent corrupt contributions. Second, disclosure provides voters with information about the identity of a candidate's financial supporters and the intensity of their support. As a result, the Court observed that disclosure

allows voters to place each candidate in the political spectrum more precisely than is often possible solely on the basis of party labels and campaign speeches. The sources of a candidate's financial support also alert the voter to the interests to which a candidate is most likely to be responsive and thus facilitate predictions of future performance in office. ${ }^{40}$

The two justifications converge in the argument that the prospect of voter awareness of a contribution may make the recipient less likely to provide a donor with favors.

The case for disclosure is almost certainly overstated. ${ }^{41}$ Although it is inherently difficult to measure the contributions not made due to disclosure laws, the significant and rapidly growing number of large contributions by

races), or the Secretary of the Senate (for Senate races), even in nonelection years. See RoberT E. Mutch, Campaigns, Congress, and Courts: The Making of Federal Campaign Finance Law 24-25 (1988).

36. See, e.g., DAVID W. ADAMANY \& GEORGE E. AGREE, POLITICAL MONEY: A STRATEGY FOR CAMPAIGN FINANCING IN AMERICA 86-87 (1975).

37. See 2 U.S.C. $\S \S 433,434,437 \mathrm{c}, 437 \mathrm{~d}, 437 \mathrm{~g}, 438$ (2002) (detailing registration and reporting requirements for political committees, and creating and empowering the FEC to enforce those reporting requirements).

38. Buckley v. Valeo, 424 U.S. 1, 67 (1976).

39. Id. (quoting and citing Louis Brandeis, Other People's Money 62 (National Home Library Foundation ed., 1933)).

40. Buckley, 424 U.S. at 67.

41. A particular problem with the theory that disclosure prevents corruption arises when, like FECA, campaign finance law imposes both disclosure requirements and contribution limits. Contribution limits are intended to prevent the large contributions that raise the potential for corruption. But if a contribution amount falls under the limit, then presumably the jurisdiction has concluded it does not present the danger of corruption. How, then, does the corruption-prevention concern (as opposed to the voter-information concern) justify its prevention? 
individuals and interest groups suggest that disclosure laws have not done much to discourage large donations. In 1996, for example, two-thirds of the value of the individual contributions given to candidates for the House of Representatives came from large donations, defined as those between $\$ 200$ and $\$ 1,000$. Similarly, $60 \%$ of the value of individual donations to incumbent Senate candidates; $65 \%$ of the value of individual donations to challengers; and $75 \%$ of the value of individual donations to open seat candidates came from large donations. ${ }^{42}$ After large individual donors, the principal participants in congressional campaign finance are PACs. The total number of PACs exploded more than sevenfold after FECA required the disclosure of PAC contributions. Moreover, the relatively small number of PACs that make very large contributions account for most PAC giving. ${ }^{43}$ The rapid growth of soft money during the 1990s was marked by a sharp rise in very large donations, including gifts in excess of $\$ 100,000$, even though due to FEC regulations these contributions were subject to disclosure. Thus, little evidence shows that disclosure has constrained the number or rate of growth of large contributions.

The effect of disclosure on voter information or voter behavior is also unclear. According to Dean Kathleen M. Sullivan, the beauty of disclosure is that it "places the question of undue influence or preferential access in the hands of the voters, who, aided by the institutional press, can follow the money and hold representatives accountable for any trails they don't like." ${ }^{44}$ But does it? Full disclosure of campaign contributions produces mountains of political finance information that must be exhaustively mined and analyzed to reveal significant patterns of giving and spending. The effectiveness of disclosure relies, to a considerable extent, on the media's willingness to examine the available information and present it to the public in a useful form before the election. Although in the aftermath of political or financial scandals the media often turn to campaign contribution reports to "follow the money" and see whether connections exist between campaign donations and legislative action (or inaction), the media generally gives less attention to campaign finance reports during the pre-election period. As one recent study of state-level campaign laws found, in most states

very few newspapers allocated even one reporter's time to analyzing campaign finance documents. Newspapers that once

42. Comm'n on Campaign Fin. Reform, Ass'n of the Bar of the City of New York, supra note 7, at 61 .

43. See id. at 64-65.

44. Kathleen M. Sullivan, Against Campaign Finance Reform, 1998 UTAH L. REv. 311, 326; accord.Samuel lssacharoff \& Pamela S. Karlan, The Hydraulics of Campaign Finance Reform, 77 TEX. L. REv. 1705, 1737 (1999) (the effcct of disclosure is "to shift vigilance over campaign eontributions away from regulatory bodies... [to] the normal workings of the politieal process by competing candidatcs or parties and by the press"). 
made the financial commitment are now cutting back. From a journalistic perspective, absent a scandal, the story seems complex and repetitive-less of a news story. As a result, newspapers are giving less space to reporting disclosed information at a time when the increasing volume and complexity of the reports would require more of an effort, not less, if the public is to get the relevant information in time for an election decision. ${ }^{45}$

And this relatively skeptical study focused on newspapers. Voters get most of their information from television. At a time when broadcasters have greatly reduced their coverage of electoral politics, it is doubtful that much campaign finance information actually reaches the public.

Nor will opposition candidates necessarily pick up the slack:

When competing candidates are well funded, both are likely to count big givers and interest groups among their contributors; neither then has an interest in raising the political finance issue. If one candidate is well funded and the other is not, the impoverished candidate simply does not have the resources to discover and publicize the amounts and sources of his opponent's funds. ${ }^{46}$

Even if the press or opposition parties analyze and disseminate contribution data in a timely manner, it will often be difficult for voters to use that information. Many wealthy individuals, corporations, trade associations, and interest groups give to more than one candidatc competing in the same race, and to the national and congressional campaign committees of both major political parties. Voters troubled by those donations can do little to punish the candidates or political parties that receive donations from particular sources if both major party opponents benefit from money from those sources.

Moreover, a voter can cast only one vote, and her concerns about sources of campaign funds may be offset by the desire to vote for the candidate who is closer to the voter on other issues. ${ }^{47}$ Voters usually cast their ballots based on multiple, varied concerns other than the sources of campaign funding - the records and characters of the candidates, their policies concerning the economy, taxation, national security, and other issues. It is doubtful that campaign contributions are at the top, or even in the middle, of this list. The vote may be too blunt an instrument to be an effective means for voters to discourage contributions from sources they view as undesirable.

To be sure, some voters may be influenced by disclosure in some elections, such as when different groups of donors give to different candidates so that the contribution information actually illuminates the

45. Michael J. MALbin \& ThOMAS L. Gais, THE DAY After Reform: SOBERING CAMPAIGN FINANCE LESSONS FROM THE AMERICAN STATES 46 (1998).

46. Adamany \& Agree, supra note 36 , at 113-14.

47. See id. at 114. 
differenees among the contenders. But it is doubtful that disclosure does much to reduce the role of special-interest money or to enable voters to discourage special-interest donations.

Disclosure is also in some tension with the value of political privacy. ${ }^{48}$ The combination of reporting and disclosure requirements and modern information technology means that the contribution practices of millions of Americans-the amounts and recipients of the donations as well as a few basic facts about the donors-are open to easy inspection by the donors' neighbors, relatives, coworkers, friends, and enemies. ${ }^{49}$ The law broadcasts information about the nature and intensity of a donor's beliefs, as well as some information about the donor's capacity and propensity to give, to "anyone who has a modem" and is interested in finding out. ${ }^{50}$ Although the Supreme Court has held that the reporting and disclosure requirements are constitutional $^{51}$ and justified by the aforementioned interests in preventing corruption and informing voters, it is still arguably a significant invasion of the financial and political privacy of donors. If donors were fully aware of the extent to which contribution information is subject to wide dissemination, some, "motivated by fear of economic or official retaliation, by concern about social ostracism, or merely by a desire to preserve as much of one's privacy as possible," 52 might well be discouraged from making contributions.

Disclosure is unlikely to deter large donors who have significant interests in government decision making and view campaign contributions as a cost of doing business. But disclosure could chill contributions by those citizens who give to candidates or organizations who, they believe, will advance views they support, but who do not want their views or affiliations broadcast over the Internet to the rest of the world. Although the potential to chill participation by ordinary citizens could perhaps be addressed by raising the disclosure threshold, disclosure inherently involves some violation of political privacy. ${ }^{53}$

48. I am indebted to William McGeveran, of the NYU Law School Class of 2002, for helping me to better appreciate the conflict between mandatory disclosure and the value of political privacy. See William A. McGeveran, The Privacy Costs of Political Contribution Disclosure, 6 U. PA. J. CONST. L. (forthcoming October 2003).

49. See Fred Bernstein, An Online Peek at Your Politics, N.Y. Times, Oct. 4, 2000, at A35.

50. Id.

51. Buckley v. Valeo, 424 U.S. 1, 60-84 (1976).

52. McIntyre v. Ohio Elections Comm'n, 514 U.S. 334, 34I-42 (1995).

53. The Supreme Court in Buckley aeknowledged that minor parties with more precarious financial bases may be vulnerable to the chilling effect of the disclosure of the identity of donors, and that the government interest in such disclosure is diminished when the candidate or party has little chance of winning the election. The Court declined to create a blanket exception for minor parties but indicated it would exempt a party from the disclosure requirement on a showing that disclosure might subject the party's donors to harassment. 424 U.S. at 68-72. In Brown v. Socialist Workers 74 Campaign Comm., 459 U.S. 87, I0I-02 (1982), the Court found that the Socialist Workers Party, which 
Nevertheless, despite these problems, disclosure remains central to campaign finance regulation. As Professor and FEC Commissioner Bradley A. Smith, a leading critic of campaign finance reform, has noted, "[d]isclosure has proven to be a popular remedy even with those generally skeptical of campaign finance regulation." 54 Indeed, skeptics like Commissioner Smith, Dean Sullivan, and Justices Scalia and Thomas would limit campaign finance regulation to disclosure simpliciter. ${ }^{55} \mathrm{Re}-$ formers would require much more regulation but still treat disclosure as "the basic foundation on which all other regulation must rest." ${ }^{\text {" Indeed, an }}$ important strand in BCRA is the extension of FECA to cover some expenditures currently exempt from disclosure as issue advocacy. ${ }^{57}$ Ackerman and Ayres, however, would abandon this fundamental component of campaign finance law and replace it with its diametrical opposite-anonymity. Their proposal requires us to consider whether anonymity can do a better job than disclosure in preventing the harmful consequences of large contributions and whether the gains in reducing the "corrupting" effects of big contributions outweigh the loss in voter information that would result from ending disclosure.

\section{B. The Anonymous Donation Booth}

Ackerman and Ayres propose that all contributions to candidates and political organizations-defined to include political parties and organizations that engage in independent campaigns concerning candidates-be made through a blind trust controlled by the FEC. ${ }^{58}$ All contributions would be anonymous. The FEC would be required to keep confidential the identities of the donors, the identities of the recipients of particular donations, and the amounts particular donors give to particular recipients. Contributors could waive this anonymity and request that the FEC disclose the fact and amount of their donations to identified recipients. But, even then, the FEC would be barred from saying anything about the size of any contribution in excess of $\$ 200$ other than reporting that the contribution was "\$200+.".59

Donors themselves would not be barred from disclosing their contributions. Donors could voluntarily report to candidates, committees, or the

had been harassed by the government in the past, was constitutionally entitled to an exemption from a state disclosure requirement.

54. BRADLEY A. SMITH, UNFREE SPEECH: THE FOLLY OF CAMPAIGN FINANCE REFORM 220 (2001).

55. See id.; Sullivan, supra note 44, at 326 (disclosure is the "most salutary" aspect of FECA); Nixon v. Shrink Missouri Gov't PAC, 528 U.S. 377, 428-30 (2000) (Thomas, J. \& Scalia, J., dissenting).

56. MALBIN \& GAIS, supra note 45 , at 30 .

57. Bipartisan Campaign Reform Act of 2002, Pub. L. No. 107-155, 116 Stat. 81 (2002).

58. ACKERMAN \& AYRES, supra note 21, at 25-44, 93-110, 199-203.

59. Id. at 201-02. 
world, the fact, size, and designated beneficiaries of their campaign contributions. However, Ackerman and Ayres would require that all contributions remain revocable within five days after delivery to the blind trust. Ackerman and Ayres contend that as a result of the five-day revocation period, a donor could never prove to a candidate, party, or PAC that she had not revoked the portion of the contribution in excess of $\$ 200$. As a result, the putative recipient could never be certain that the donor had actually made a donation-or a donation of the particular (large) size claimed. Relying on what they call the "mimicry principle"60 (and what other people might call more simply "lying"), they assume that both donors of $\$ 201$ and donors of $\$ 10,000$ can claim to have made $\$ 10,000$ contributions. Both can flourish $\$ 10,000$ checks before the designated recipients. But some donors will subsequently revoke their $\$ 10,000$ checks and replace them with $\$ 201$ checks, and the FEC will report the $\$ 10,000$ donations and the $\$ 201$ donations the same way -as $\$ 200+$. In this " "noisy' environment, full of potentially misleading signals," ${ }^{61}$ a candidate or party could never be sure whether the putative donor had actually made the large contribution he claims to have made. Candidates and parties, thus, would be less inclined to respond to their donors since they would be uncertain whether the donors really were significant supporters. In turn, those donors who give primarily to win favors from and gain access to officeholders would stop giving, or give less, since their donations would no longer pay off as they had before. Ultimately, the candidate-contributor relationship would erode, and the role of special-interest money in financing federal election campaigns would dry up.

Ackerman and Ayres flesh out their proposal with additional measures designed to maintain anonymity. One concern is that a donor who makes a very large contribution could pieree the veil of anonymity since a sudden increase in the candidate's blind trust similar in size to the donation would tend to validate the contribution claim. They deal with this possibility in two ways. First, they would deploy a "secrecy algorithm" when a candidate receives a small number of very large gifts. The algorithm would serve to hold baek some of the money for a time and permit distribution to the candidate over the next several weeks. ${ }^{62}$ Second, recognizing that the largest contributions would frustrate even the secrecy algorithm, they would place a ceiling on how much a donor can give to a particular candidate both in any two-week period and over the course of a campaign. ${ }^{63}$

The Ackerman and Ayres plan constitutes a bold departure from campaign finance law's traditional commitment to disclosure. It prompts

60. Id. at 101 .

61. Id.

62. Id. at $104-08$.

63. Id. at 113-18. 
several questions. First, can the secrecy essential for the plan to work be maintained? Second, will anonymity be more successful than disclosure in undermining the quid pro quo relationship that can result from large campaign contributions? Third, can the system be circumvented by other methods of providing financial support to candidates? Finally, are the benefits of secrccy justificd by the loss in public information concerning the identities and intensity of support of the financial backers of candidates, major parties, and PACs?

\section{Can anonymity be maintained?}

Whether anonymity will work depends on the integrity of the blind trust staff who receive and process campaign contributions. Blind trust staff sympathetic to one candidate might try to discredit that candidate's opponent by leaking to the prcss the details concerning a contribution from an embarrassing source. Even if the staffer could be punished for the unauthorized disclosure, media reports concerning otherwise anonymous campaign contributions are probably constitutionally protected..$^{64}$ Alternatively, a staffer allied with a particular donor might surreptitiously convey the fact and size of the donation to the recipient. Leaving aside questions of staff partisanship or bias, there is, as Ackerman and Ayres acknowledge, "the danger of sheer corruption-donors and politicians bribing trust officials to leak the data they need to grease the wheels of the quid pro quo." ${ }^{.65}$

To reduce the temptation to take graft, Ackerman and Ayres would provide "premium salaries" for blind trust staff and impose a "ten-year ban on cmployment by any big donor or candidate." ${ }^{\text {"67 }}$ More weakly, to control against partisan staff behavior, they would mandate "antifraternization regulations that bar blind trust officials from associating with candidates or their representatives outside the office." ${ }^{, 68}$ Ultimately, though, they acknowledge that it will be up to the leaders of the FEC "to foster a spirit of genuine independence for their watchdog agency-a spirit that will inspire officials to take pride in a job well done." ${ }^{69}$ This is a tall order for the FEC-one of the most criticized federal agencies; ${ }^{70}$ another part of the Ackerman and Ayrcs program significantly revamps the FEC. ${ }^{71}$

64. See Bartnicki v. Vopper, 532 U.S. 514 (2001).

65. ACKERMAN \& AYREs, supra note 21, at 99; $c f$. Kenneth R. Mayer, Answering Ayres, REgUlATION, Winter 2001, at 24, 28 ("The possibility of private traffic in contribution data leads to all manner of pathologies. Candidates could seek damaging information about their opponents in the hope of exposing contributions from out-of-favor interests or individuals.").

66. ACKERMAN \& AYRES, slupra note 21 , at 99.

67. Id.

68. Id. at 100.

69. Id.

70. See, e.g., Project FEC, supra note 6. The FEC has been criticized as ineffective and riven by partisanship. See id. at 7-18. The FEC consists of six members, appointed by the president with the advice and consent of the Senate, who serve for six-year terms. 2 U.S.C. $\S 437 \mathrm{e}(\mathrm{a})(1),(2)(\mathrm{A})(2002)$. 
It is unclear whether the combination of high salaries, anti-revolving door and antifraternization rules, and a reconstituted FEC could assure the maintenance of anonymity. As Professor Ayres has acknowledged, "I am under no illusion that this (or any other) system of anonymity would be completely successful in keeping candidates uninformed." ${ }^{2}$ Of course, no regulatory system is perfect, and some violations of the rules are inevitable. The question is whether the system works in most cases and whether the public has confidence that the anonymity rules are generally being followed.

The empirical evidence concerning the integrity of anonymous contribution systems is uncertain. As Professor Ayres and coauthor Jeremy Bulow noted in an earlier article, a number of states mandate that judicial candidates be kept uninformed about donations to their campaigns. ${ }^{73}$ Ayres and Bulow found that in at least some states these rules have effectively kept judges in the dark about the identity of their financial backers, although they note that critics have called the effectiveness of these requirements into question. ${ }^{74}$

In the United Kingdom, the Committee on Standards in Public Life ("Committee") ${ }^{75}$ recently came out in favor of the disclosure of campaign

No more than three commissioners may be affiliated with any one political party. See id. at $\S$ $437 \mathrm{c}(\mathrm{a})(1)$. In practice, this has meant that the FEC is composed of three Democrats and three Republicans. The president does not appoint a chair; rather, the position rotates annually among the members. Moreover, despite the provision for presidential appointment, in practice the commissioners are picked by congressional party leaders. They are usually "chosen on the basis of their political allegiances rather than their qualifications and commitment to effective administration and enforcement of the law." ProjeCt FEC, supra note 6, at 15. With six commissioners, divided three-to-three along partisan lines, and four votes necessary to take action, the FEC has been deadlocked in many politically charged cases. See id. at 53-57. In other cases, the members from both parties may act together to block proceedings hostile to the interests of the parties. See $i d$. at 11-13. The FEC is also hobbled by a cumbersome, multistep enforcement process that values conciliation over vigorous action to prevent and penalize violations of the law, a lack of resources, and congressional retaliation when the agency actually seeks to carry out its mandate and vigorously enforce the campaign finance laws. See id. at I3$15,19-23,71-78$.

71. ACKERMAN \& AYRES, supra note 21, at 128-39. Ackerman and Ayres would replace the sixmember politicized FEC with a five-member body composed solely of retired federal judges, each serving for one, nonrenewable ten-year tern. See id. at 129-30. According to the authors, this will create a body that is both nonpartisan and decisive. See id. at 130. Their proposal would also simplify the ability of the agency to bring enforcement actions and would protect the agency's budget by insulating it from annual congressional review. See id. at 133, 135.

72. Ian Ayres, Disclosure Versus Anonymity in Campaign Finance, in Nomos XLII, Designing Democratic Institutions 19, 35 (lan Shapiro \& Stephen Macedo eds., 2000).

73. Ayres \& Bulow, supra note 22, at 87I-75.

74. Id. at $873-74$ n. 138 (citing sources claiming that anonymity "doesn't work" and "is . . nearly impossible to enforce."); Mayer, supra note 65 , at 28 (noting " $[t]$ he dismal track reeord of restrictions on the dissemination of political information").

75. The Committee on Standards in Public Life is a standing committee of Parliament created by then-Prime Minister John Major in 1994 to "examine current concerns about standards of conduct of all holders of public office, including arrangements relating to financial and commercial activities." Following Labour's election victory in 1997, the Committee's terms of reference were extended to 
contributions to political partics, explicitly rejecting blind trusts as an alternative, noting that "there must be considerable doubt whether they ensure anonymity." ${ }^{976}$ The Committee suggested that the problem was not so much the integrity of blind trust administrators, but the danger that a "cynical" public will not believe in the effectiveness of the trust and will instead "conclude that a donor can easily let it be known to the beneficiary that he or she has made a substantial contribution." incentive to inform the candidate about the full size of his contribution, the public may doubt that anonymity can be maintained. Public confidence in the effectiveness of the regulatory regime is particularly critical in the campaign finance setting, where the protection of public belief in the legitimacy of the electoral process has long been a crucial factor in the appraisal of election laws. Indeed, getting the public to believe in the integrity of the anonymity system may be more difficult than actually maintaining anonymity.

\section{Will anonymity alleviate the potentially corrupting effects of large contributions?}

As one pair of critics has noted, the Ackerman and Ayres proposal relies not simply on anonymity but on a "culture of widespread mistrust," in which donors lie about their contributions, and candidates are encouraged to disbelieve the claims of donors. But how many donors actually will lie about their donations, go through the trouble of writing a $\$ 10,000$ check, show it to the candidate, send it to the blind trust, and then revoke the donation and replace it with one for $\$ 201$ ?

Surely the personal friends, partisan allies, or ideological backers of the candidate will have little interest in these tricks. These donors genuinely and strongly want the candidate to win. Other donors may have worked and supported the candidate in the past and look forward to doing so in the future. Given their regular contacts with the candidate, they are more likely to be honest and give what they say they are going to give. Many donors are honorable individuals and will do exactly what they say they will do.

But certainly some donors may be dishonest about the size of their contributions. Donors who regularly do business with the government or engage in activities subject to extensive government oversight give not out of affcction or support for the candidate, but to gain access to the

include "issues in relation to the funding of political parties." See Fifth Report of The Committee on Standards in Public life, The funding of Political Parties in the United Kingdom, Volume 1: REPORT 15-16 (1998).

76. Id. at $\$ 4.72,61-62$.

77. Id. at 62 .

78. Geoffrey Brennan \& Alan Hamlin, Paying for Politics, in Nomos XLII, supra note 72, at 55, 64. 
Representative or Senator who sits on the committee with jurisdiction over the donor's enterprise. They do not particularly care whether the donee wins or loses so long as he is willing to meet the donor with respect to a legislative or regulatory matter affecting the donor's business.

Although many reformers and the general public regard campaign contributions as a device for donors to "bribe" officeholders, to many donors the system resembles "extortion" with officeholders pressuring them to make contributions as the price of access. These unwilling and resentful contributors may very well take advantage of the opportunity Ackerman and Ayres give them to subvert officeholder pressures by lying about the size of their contributions. Even if only a relative handful lie, so long as candidates are aware of the possibility that some of their donors may be lying, the seeds of mistrust are planted, and candidates may grow to distrust their donors (or at least their "access" donors) more generally. Ackerman and Ayres count on this outcome to shatter the quid pro quo relationships that grow out of access contributions.

Paradoxically, Ackerman and Ayres undermine the very "culture of widespread mistrust" necessary for their program to work by requiring that ten years after each election the FEC release to the public a complete contributions list indicating the donor, amount, and recipient of each contribution. This enables donors to verify that their gifts were, in fact, credited to the intended recipient. ${ }^{79}$ In the "culture of widespread mistrust" on which they rely, it would be as reasonable for donors to mistrust the FEC staff as it is for candidates to mistrust donors. However, if donors look to the audits to check up on the blind trust staff, then presumably politicians, particularly politically powerful incumbents, will look to the audits to check on their donors' claims. Although Ackerman and Ayres contend that "after ten years, the data will be too stale for donors and politicians to use as a basis for future-oriented dealings," ${ }^{80}$ the prospect of ten-year audits may have a devastating effect on the willingness of donors-particularly the ongoing political players most likely to take advantage of the anonymity schemeto lie about their donations. As Professor Kenneth Mayer contends, "When a false claim becomes known, the people who made it would see their credibility drop to zero in all future interactions. Nobody with long-term stakes in the political process would be willing to risk that." ${ }^{" 81}$

Ackerman and Ayres need some other mechanism that assures donors that their contributions are spent as they intend and keeps politicians in the dark about the size of the donations thcy receive.

79. ACKERMAN \& AYREs, supra note 21, at 99, 202.

80. Id. at 99.

81. Mayer, supra note 65 , at 27. 


\section{Can the blind trust be circumvented?}

Assuming the disincentive to lying created by the ten-year audit can be addressed and anonymity maintained, will donors be able to outflank the secret donation booth and use their campaign funds to establish relationships with candidates? The most plausible technique is the independent expenditure. Instead of contributing money to a candidate, a would-be donor could spend money directly on communications to the voters that sing the candidate's praises or attack his opponent. In Buckley v. Valeo, the Supreme Court determined that in "the absence of prearrangement and eoordination of an expenditure with the candidate or his agent, $"{ }^{\prime 2}$ an independent expenditure does not present the same quid pro quo danger as a contribution to the candidate and, thus, cannot be restricted. ${ }^{83}$ Although the Court may well have underestimated the ability of individuals and interest groups to use independent expenditures to win a candidate's gratitude, the prohibition on independent expenditure limits remains a part of constitutional doctrine, and an independent expenditure provides an important alternative to the contribution for aiding a candidate.

Ackerman and Ayres address independent expenditures by requiring that contributions to organizations that make independent expenditures also be made through the blind trust so that candidates would not know the identities of donors actually paying for the independent expenditurcs. This is, at best, a partial control on the independent expenditure end-run. First, in many situations the donors seek a benefit not for themselves individually but for their interest group. Individuals who give to the car dealers' PAC, the beer distributors' PAC, the trial lawyers' PAC, and so on, are not looking for an individual reward but for recognition of their interest group's role in aiding the candidate. Using the blind trust to mask group members' identities and individual donation amounts does nothing to hide the independent spending program. If such a group engages in independent spending, the benefited candidate can easily be made aware of just how much the group spends. Second, wealthy individuals looking for personal recognition by the candidate do not need to make contributions to a group. They ean take out ads direetly, so their spending is also outside the blind trust's cloak of anonymity.

Still, independent expenditures may not pose a serious risk to the goals of the anonymity rcgimc. The Ackerman and Ayres proposal primarily targets individuals and groups who buy access with donations. ${ }^{84}$ Independent expenditures are inconsistent with the measured, pay-to-play

82. 424 U.S. 1,47 (1976).

83. Id. Individuals and organizations that engage in independent spending, however, can be required to disclose sources and amounts of donations they receive and the expenditures they make above a threshold level.

84. ACKERMAN \& Ayres, supra note 21 , at 171-73. 
support that their contributions represent. As previously noted, these donors often give to both candidates in a contested race and, more generally, give to both major political parties. But an independent expenditurc clearly supports one candidate or opposes another. The spender directly seeks to influence voter decision making. It would be highly implausible for a donor to make independent expenditures advocating the election of both candidates in a race or to take out ads backing both Democrats and Republicans. In other words, even though the independent expenditure does not involve the contribution of money to a candidate, it is actually a more public and emphatic form of support for that candidate than a contribution.

Ideological interests, partisan groups, and individuals strongly committed for or against a particular candidate, interest, or party make indepcndent cxpcnditures and would probably do so under the anonymity regime. But these groups are also likely to make large contributions through the blind trust. They would use the independent expenditure not to avoid the anonymity aspect of the blind trust but to circumvent the dollar limits on contributions, much as such groups currently use independent expenditures and issue advocacy to avoid contribution limits under FECA's disclosure regime. By contrast, inside-the-Beltway players who give as part of their legislative lobbying are unlikely to want to come out so dramatically on one side, and, thus, alienate the opposing candidate or members of that candidate's party. They are unlikely to turn to independent expenditures in an anonymity regime.

\section{Are the costs of shifting from disclosure to anonymity justified by the gains?}

Assuming that anonymity and public confidence in anonymity can be maintained, that the audit problem can be solved without public disclosure, and that donors will not turn to independent expenditures to replace the contributions they are discouraged from making-in other words, that anonymity works-what are anonymity's costs, and are they worth the gains?

The principal cost of anonymity is the loss of information both for voters during an election and for the general public between elections. Under the Ackerman and Ayres plan, neithcr voters in the pre-election period, nor the public in the years immediately aftcr the election, will know anything about the identities or intensity of support of the financial backers of candidates and officeholders. The only information will come out ten years later-far too late to affect most current electoral decisions. The loss of information concerning "access" contributors is not likely to be a problem. The voters would lose information about the identity of a candidate's backers, but so would the candidates. As a result, either those contributions will dry up since such donors will no longer be able to leverage their 
contributions into access, or, even if they continue to make donations, politicians' inability to verify donation amounts will eliminate the danger of quid pro quo donations. Voters would have no need to use contribution information to police the integrity of elected officials because the threat to public integrity would disappear.

However, as previously noted, some contributions are made not to influence the candidate-as-officeholder but to influence the outcome of an election. These donors give not to gain postelection access but because, due to any number of ideological, partisan, ethnic, economic, or cultural concerns, they want one candidate or party to win. They are unlikely to be discouraged by anonymity. Indeed, the anonymity regime may encourage politically controversial groups to give more. Anonymity, however, would deny voters information concerning which ideological groups are backing particular candidates and how intensely they are doing so. Although in some cases disclosure would not provide much additional information beyond the fact of support-endorsements might have made that cleardisclosure would provide an indication of the financial intensity of that support. In situations in which support comes from outside the state or district, from groups lacking local constituencies, disclosure may provide the only information about the donors' involvement in the election. ${ }^{85}$

As I have previously suggested, the value of the information generated by disclosure has probably been overstated. Contribution information may not be communicated effectively to voters. Even when it is, a voter may not be able to use her vote to punish a candidate for aecepting contributions from sources she deems undesirable because, overall, she still prefers that candidate. Still, there are likely to be some elections in which donors are closely identified with a politically significant position, and conflicting groups pour money into the war chests of competing candidates. In those elections, disclosure could enable the voters to understand what is at stake, ${ }^{86}$ and nondisclosure of contribution data would reduee the ability of voters to make informed decisions.

Disclosure may also provide information that is valuable outside the electoral context. Campaign finance reports tell the public about the identity and intensity of support of an officeholder's financial backersinformation that may prove a useful framework for assessing legislative votes and other official actions and, more generally, for evaluating the connection between campaign financing and the behavior of government actors between campaigns. Even with a limited direct impact on a

85. See, e.g., Thomas B. Edsall, Questions Raised About Donors to Georgia Lawmaker's Campaign, WASH. Post, Aug. 13, 2002, at A6 (noting that Georgia Representative Cynthia McKinney, a congressional critic of Israel, had received substantial contributions from out-of-state Muslim and pro-Palestinian groups, while her Democratic primary opponent, Denise Majette, an African American woman like McKinney, had received substantial financial support from out-of-state Jewish groups).

86. See id. 
campaign, disclosure may enrich public understanding of how government works and how decisions are influenced. Such information would be lost in an anonymity regime. To the extent Ackerman and Ayres's plan reduces the role of campaign contributions in influencing government, the information lost through anonymity is less important. But some information that may help the public evaluate the actions of elected officials still will be lost.

In addition to reducing information, anonymity-by eliminating the opportunity for donors to leverage contributions into access, and by similarly denying officeholders the ability to make access contingent on contributions-could be a disincentive for many wealthy private donors to make large contributions. Like a contribution limit, anonymity could reduce candidates' resources and, in turn, the amount of information that campaigns provide to the voters. Candidates would also have to spend more time and effort on fundraising. They will search for new ways of raising money and evading regulatory restrictions. Self-funded candidates, who are not dependent on private donations, would gain. Moreover, anonymity would operate as a particularly odd kind of contribution limit. Only "access" donors would be discouraged from giving. Ideological, partisan, and other donors interested in actually influencing the election would continue to make individual donations as well as independent expenditures. Thus, not only would the volume of private contributions diminish, but also the balance would be tilted from inside-the-Beltway interest groups with contributions linked to their lobbying agendas toward more ideological and partisan groups interested in shaping the face of govcrnment.

The secret donation booth would thus have a problematic impact on campaign finance. Access contributions would be reduced, but ideological interests would loom much larger in the diminished pool of campaign dollars. That would be a potentially serious consequence if secrecy were Ackerman and Ayres's only campaign reform device. But that is not the case. Rather, they have harnessed anonymous donations to an ambitious program of public funding. Under their plan public funds would offset the loss of private donations and the tilt toward ideological contributions likely to result from anonymity. The secret donation booth, thus, is intertwined importantly with their public funding plan.

\section{Disclosure or Anonymity?}

The choice between a disclosure or anonymity regime is a close one. The empirical question of whether anonymity can be maintained is uncertain. Certainly, Ackerman and Ayres must develop some means other than public disclosure for monitoring the behavior of blind trust staff. If monitoring can function successfully, then there is no reason to assume a priori that anonymity cannot be maintained. Public skepticism, of course, may 
pose a greater barrier than actual evidence of structural flaws in the anonymity system. Ackerman and Ayres still must persuade the public that anonymity can be sustained.

Assuming anonymity can be made to work-a big if-Ackerman and Ayres make a strong case that anonymity will do a better job than disclosure of checking the corrupting effects of large contributions. There is, in fact, little evidence that disclosure has discouraged any special-interest contributors or that disclosure has curtailed the ability of donors to obtain access, if access is their goal. Disclosure is a failed strategy for curbing the effects of large campaign contributions on government integrity. Anonymity seems far more likely to curtail the pay-to-play donations of accessoriented special-interest donors.

Anonymity, however, also will reduce the amount of information concerning ideological donations aimed at electing a candidate. Currently, such contributions are likely to go to only one candidate per contest. Disclosure of the amounts and sources of such ideological contributions can provide voters with useful information about candidates. Information about ideological contributions would be lost under the Ackerman and Ayres regime.

Is the probable discouragement of what Ackerman and Ayres call "pork barrel donations" ${ }^{87}$ worth the new confidentiality to be accorded to ideological donations, especially when the size of ideological donations may grow under the increased contribution limits Ackerman and Ayres also propose? That is difficult to decide. Pork barrel donations, as the Supreme Court observed in a related context, involve the use of "'resources amassed in the economic marketplace' to obtain 'an unfair advantage in the political marketplace." ${ }^{88}$ Although the size of their political war chests have "little or no correlation to the public's support for [their] political ideas, ${ }^{89}$ the campaign contributions of pork barrel donors can have an enormous impact on both the electoral process and government action. Yet, such donors typically have little interest in the outcome of the election itself. For them, an election is not a vitally important moment for democratic decision making. It is an opportunity to get a foot in the door in subsequent government deliberations or an occasion for officeholders to exploit donors' needs for such access by extracting campaign contributions. Ideological donors, by comparison, participate eagerly in the election itself, using their funds in ordcr to influence electoral discussions and voter decision making.

87. ACKERMAN \& AYres, supra note 21, at 171-72.

88. Austin v. Michigan Chamber of Commerce, 494 U.S. 652, 658-60 (1990) (quoting FEC v. Massachusetts Citizens for Life, Inc., 479 U.S. 238, 257 (1986)).

89. Id. 
Yet large ideological donations may be in tension with at least one central strand of democratic politics-voter equality. Many ideological organizations benefit from the financial support of their wealthy backers. Their contributions, too, may reflect resources amassed in the economic marketplace, not public support for their ideas, and thus threaten to give some groups more say in the electoral process than their numbers would otherwise warrant.

Nor is the line between pork barrel and ideological giving always clear. Some pork barrel interests may also give for ideological reasons-as when one candidate takes positions clearly threatening their material concerns - not for access. In such an election, they might give generously even if their giving has to be anonymous, but the voters would be unaware of their role in financing the candidate they are backing.

It is uncertain whether anonymity or disclosure is the better approach. Given the central role disclosure has long played in the American campaign finance regime, Ackerman and Ayres may not have done quite enough to displace it at the national level. But $I$ hope that reformers read this book and experiment with anonymity systems at the state and local levels. State and local campaign financing schemes may test the functionality of anonymity and assess its practical impact on contribution practices. If anonymity works at the state or local level, it could then be tried in fedcral clections. Ackerman and Ayrcs persuasively show that anonymity is worth a try at the subnational level, even if the case for a federal-level switch has not quite been made yet.

The choice between anonymity and disclosure is a difficult one; it is also tempting to say that it is, ultimately, not a very important one. Neither anonymity nor disclosure actually do anything to address the dependence of candidates on private wealth (their own or that of their large donors), the lack of financial competitiveness that marks so many elections, or the burdens of fundraising that fall upon candidates. We know from the cxpcrience of the last thirty years that disclosure fails on all these counts. But anonymity is unlikely to do better. Under a regime of anonymity, candidates would still depend on private donations to fund their campaigns. Moreover, without access donations, candidates would need to spend more time and effort on fundraising. They would remain under pressure to shape their positions to win the financial support of politically active interest groups. The wealthy, the organized, and groups with interests at stake in the political process would still be the focal point of fundraising. Indeed, with elected officials no longer able to "sell" access to donors, they might be compelled to pander even more strongly to the interests of donors and potential donors. Although anonymity might reduce the flow of accessoriented funds to incumbents, it would do nothing to help challengers raisc money. With studies suggesting that the ability of challengers to raise a 
critical mass of funds at the beginning of an electoral race is more crucial than their ability to financially match incumbents, ${ }^{90}$ the anonymity system would do little to promote competitive elections.

At its best, then, anonymity alone would ameliorate the worst implications of campaign fundraising for the integrity of government decision making. But anonymity would do nothing to make elections more consistent with the norm of voter equality or to reduce the dependence of candidates on the funds (and views) of large donors. Thus, the more significant component of the Ackerman and Ayres plan is the shift in campaign financing from private contributions to public money.

\section{II}

\section{Public Funding Through Vouchers}

\section{A. The Patriot Money Plan}

Ackerman and Ayres propose to reform the financing of federal elections largely, albeit not exclusively, with public money. Public funding is not a new idea nor is the case for public funding difficult to make, despite the unwillingness of Congress to enact a congressional public-funding program. Public funding reduces the disproportionate influence of wealthy donors and interest groups on elections and government decisions. It promotes competitive elections by providing campaign resources to challengers and newcomers otherwise unable to raise funds from private donors. It reduces the burden of fundraising for candidates, thereby making it easier for more candidates to compete, for candidates to spend more time campaigning, and for elected officials to devote more time to their jobs. ${ }^{91}$

The Ackerman and Ayres plan would differ from other forms of public funding by relying on vouchers provided to registered voters, rather than government grants to candidates or parties-the public funding mechanism in the presidential election and in all state and local publicfunding systems. ${ }^{92}$ The voter would be able to contribute the voucherwhich Ackerman and Ayres label "Patriot money"-to federal candidates, the political parties, or PACs that contribute to or make expenditures with respect to federal candidates. ${ }^{93}$ In the first election cycle, each voter would get a $\$ 50$ voucher, of which $\$ 10$ would be allocated to House of Representatives races, $\$ 15$ to Senate races, and $\$ 25$ to the presidential race. ${ }^{94}$ These numbers would be adjusted for inflation in future elections.

90. See, e.g., FRANK J. SORAUf, INSIDE CAMPAIGN FINANCE: MYTHS AND REALITIES 17578 (1992); GARY C. JACOBSON, MONEY IN CONGRESSIONAL ELECTIONS (1980).

9I. See generally Public Funding, supra note 16, at 568-83 (describing the benefits of public campaign funding).

92. ACKERMAN \& AYREs, supra note 21, at 66-68.

93. Id. at 70-75.

94. See id. at 76-78. Ackerman and Ayres further provide that in a presidential election in which the incumbent is running for re-election, $\$ 10$ of the $\$ 25$ presidential voucher is allocated to the 
The Patriot money plan would make public vouchers the dominant but not exclusive form of funding campaigns. Candidates could still accept private contributions. Moreover, unlike some reformers who want to drive down the total amount of campaign money, ${ }^{95}$ Ackerman and Ayres aim to increase campaign spending above current levels. A $\$ 50$ voucher for each of 100 million voters would generate $\$ 5$ billion in public funds; in the 2000 election, private funding reached roughly $\$ 3$ billion. ${ }^{96}$ Although the secret donation booth could significantly reduce private donations-they guesstimate that private donors will contribute no more than $\$ 1$ billion-the total of public and private dollars would still bc $\$ 6$ billion (well above current levels), and public funding would predominate. ${ }^{97}$

Recognizing that many Americans may fail to use their vouchers or that private contributions may not drop as much as they anticipate, Ackerman and Ayres propose further measures to assure both that campaigns are funded at adequate levels and that public money predominates over private money in the system. If the combination of Patriot and private dollars falls significantly below the pre-enactment baseline, the FEC would double the size of the Patriot voucher in the next election cycle. ${ }^{98}$ In addition, if the combination of private donations and Patriot money actually used dips so low as to constitute a "severe drought" during the election at issue, the FEC would grant, periodically during the campaign, a "compensating bonus" to each candidate in proportion to the value of the Patriot dollars he or she has collected. ${ }^{99}$ Finally, in the event that, secret donation booth notwithstanding, private dollars continue to constitute a significant fraction of campaign money, the FEC would increase the Patriot allocation in the next election (not the current one) with the aim of producing a twoto-one Patriot-to-private funding ratio. ${ }^{100}$

Finally, unlike all other public-funding programs, there would be no spending limit for individual candidates. A candidate could spend all the Patriot and private dollars he or she could collect.

primaries and $\$ 15$ to the general allocation. $I d$. at 79 . There is no similar allocation of vouchers in an open-seat presidential election or in House or Senate elections. Id. at 79-82.

95. See Public Campaign, Clean Money Campaign Reform, http:/www.publiccampaign.org/ publications/CleanMoneyCampaignReform.pdf (claiming that a leading problem of current campaigns is that they are "too expensive" and justifying the "clean money" program because it "allows the greatest reduction in the cost of campaigns.").

96. ACKerman \& AYres, supra note 21 , at 83.

97. Id. at 83-84.

98. Id. at 86 .

99. Id. at 86 . The FEC would have this power only in the first eight years after the Patriot money system becomes law. $I d$.

100. Id. at $89-90$. 


\section{B. The Promises and Pitfalls of Vouchers}

The principal distinctive feature in the Ackerman and Ayres plan is the use of the voucher. Vouchers go directly to voters, who may use them only to make contributions to candidates. ${ }^{101}$ Thus, the analysis of the Ackerman and Ayres program is less about public funding per se than about vouchers.

\section{Why Vouchers?}

Vouchers would resolve two important interrelated operational difficulties for any public funding plan, determining (1) which candidates qualify for public funding, and (2) how much each candidate receives. These two questions arise because multiple candidates may qualify for listing on the ballot, but they may differ substantially in the extent of their public support. Although one goal of public funding is to provide resources for newcomers, outsiders, and challengers, some reformers are concerned that public funding might artificially inflate frivolous or marginal candidacies. Funding all ballot-qualified candidates equally would divert funds from the main competitors to peripheral candidates; funding all candidates at the same rate would also either drive up the total cost of the publicfunding program or reduce the amount of funding any one candidate eould receive.

All public-funding programs have to reconcile competing concerns. The goal of promoting electoral competition provides an impetus to low thresholds and generous grants to challengers and newcomers. The goal of using public funds to reduce the dependency of officeholders on private donations pushes towards focusing the program on the financing of the major candidates. Limited resources force the government creating a publicfunding system to confront trade-offs and choose between treating all candidates equally or allocating funds based on some measure of the "importance" of the candidate.

Most current public-funding programs discriminate among candidates by requiring a candidate to demonstrate a base level of support in order to qualify for funding; many also set the amount the candidate ultimately receives according to some measure of private support. ${ }^{102} \ln$ the presidential

101. Voters may give their vouchers to political parties or to other political committees, but parties and committees may use the vouchers only to support candidates. See $i d$. at $210-11$.

102. See, e.g., N.J. Stat. 19:44A-33 (providing for payments of public funds to gubernatorial candidates who raise a threshold amount of $\$ 50,000$; the amount of publie funds paid to each candidate is determined by doubling the amount of private contributions the candidate has received, up to $\$ 1,500$ per contributor, and up to a total funding cap of $\$ 1,350,000$ in the primary election and $\$ 3,300,000$ in the general election). See generally MALBIN \& GAIS, supra note 45, at 56-59 (explaining that to be eligible for public funds, "candidates must usually raise a specific amount of money, in small amounts, from individuals who in some cases must come from specified geographical areas," and that most states distribute funds via matching grants but some use flat grants). 
general election, for example, the nominee of a major party-defined as a party whose presidential candidate received $25 \%$ of the vote in the immediate past presidential election-automatically qualifies for a full public grant. The nominee of a minor party - defined as one whose presidential nominee polled between $5 \%$ and $25 \%$ of the vote in the previous presidential election-also qualifies for funds but receives a smaller grant based on the party's share of the vote in the past election. ${ }^{103}$ Other candidates receive no public funding at all before the election, although a candidate who wins $5 \%$ of the vote is eligible for a postelection payment based on his share of the popular vote. ${ }^{104}$

This reliance on prior party electoral success is, in several ways, an inappropriate basis for determining the eligibility and amount of public funding. The system burdens independent candidates with significant popular support, like John Anderson in 1980 or Ross Perot in 1992, since these candidates cannot cite to a party track record that would qualify them for public funds. On the other hand, a good showing by a minor party in one election can generate public funding for a much weaker eandidate of the same party with a completely different philosophy who is able to capture that party's electoral apparatus in the following election. For example, Pat Buchanan was able to convert Ross Perot's significant 1996 vote into $\$ 12.6$ million in public funds but less than half a million popular votes in 2000 . Beyond the problems with relying on historical data, the statutory thresholds clearly favor the major parties: ${ }^{105}$ Ralph Nader received nearly 2.9 million votes and $2.74 \%$ of the total popular vote but received no public funds in 2000-either before or after the election. Moreover, prior party electoral success is not even available as a funding criterion in primary elections. Public-funding systems that support primary candidates typically require a candidate to raise a threshold amount of private contributions in order to qualify for public dollars. ${ }^{106}$ A qualifying candidate then receives either matching funds, with each dollar of additional private funding up to a ceiling amount per donor generating one or more dollars of public funds until a cap on the maximum public grant the candidate may receive is reached; ${ }^{107}$ or all qualifying candidates may be given an equal flat grant. ${ }^{108}$

103. 26 U.S.C. $\$ 9004(2002)$.

104. Id.

105. This campaign finance system was intentionally designed to favor major party candidates. See Bucklcy v. Valeo, 424 U.S. 1, 98 (1976).

106. See, e.g., 26 U.S.C. $\S 9033$ (2002) (to receive public funding for presidential primaries, a candidate must obtain $\$ 5,000$ in contributions from residents of each of twenty states); KY. REv. STAT. ANN. 121 A.060 (public funding for slate of governor and lieutenant governor in primary election predieated on the slate raising $\$ 300,000$ in qualifying contributions).

107. See, e.g., 26 U.S.C. $\$ 9034$ (2002) (qualifying presidential primary candidates rcceive dollarfor-dollar matehing grant up to $\$ 250$ for each private contribution until total funding cap is reached).

108. See, e.g., ARIz. Rev. STat. § 16-95I (2002). 
The Ackerman and Ayres voucher plan solves the "who gets them?" and "how much do they get?" questions by delegating those decisions to voters. Instead of government-set qualifying thresholds, flat-grant amounts, and matching thresholds, rates, and ceilings, the voters individually choose which candidates will receive their vouchers, and the voters in the aggregate decide how much public money any one candidate will receive. ${ }^{109}$ This avoids the pathologies resulting from the use of historical party data in flat grant systems for presidential elections. Pat Buchanan's public money in 2000 would have reflected the extent of public support for him in 2000, not the public support for the very different views and personality of Ross Perot in 1996. Conversely, John Anderson in I980 or Ralph Nader in 2000 could have received public funds, notwithstanding the lack of a presidential election track record.

Not only would these decisions be based on current political realities, but also the possibility of government manipulation of the rules governing eligibility and grant size would be avoided. ${ }^{110}$ The Patriot money voucher lets the voter decide whom to favor. Candidates would receive public financial support only to the extent that they enjoy actual current public support. The only decision the government makes is the monetary value of the voters' Patriot dollars.

Ackerman and Ayres urge that the choice of vouchers over government grants directly to candidates has normative as well as operational significance. For them, the basic rules of campaign financing should track the basic rules of voting, including one person, one vote. As they put it, "It isn't enough to count every vote equally on election day. The American citizen should also be given a more equal say in funding decisions." 111 But equalizing voters' financial influence over elections could be accomplished through government grants directly to candidates. Vouchers do not just equalize. Rather, according to Ackerman and Ayres, vouchers increase public participation in the political process by the creation of a new aet of political engagement - the transmission of the voter's Patriot dollars to her designated candidates. They call this "the citizenship effect": "By casting their patriotic dollars, Americans will be giving renewed social meaning to their self-understanding as free and equal eitizens, engaging in democratic deliberation."112

109. See ACKerman \& AYres, supra note 21, at 210-12.

110. Although the usual assumption is that government will manipulate the rules to favor major parties and incumbents, some systems equalize the funding for all qualifying candidates. See, e.g., ARIZ. Rev. STAT. \& 16-951 (2002). In one state, the law favors challengers over incumbents. See 17 VT. STAT. ANN. 2855(b)(3) (1999) (legislating that public grant to the incumbent shall be only $85 \%$ of the grant to a challenger).

111. ACKERMAN \& AYres, supra note 21 , at 4.

112. Id. at 15 . 


\section{Problems with Vouchers}

Ackerman and Ayres make an appealing case for the voucher approach to public funding. But vouchers have several serious operational shortcomings. The normative benefits of a new form of public participation may come at the price of frustrating some of the goals of public fundingpromoting electoral competition, leveling the electoral playing field, and reducing the burdens of fundraising.

One problem with vouchers is uncertainty. The candidates' public funding depends entirely on voters casting their vouchers. But just as we have no idea how many people will vote on election day, candidates have no idea how many voters will cast their vouchers, let alone the number of vouchers each candidate will receive. Ackerman and Ayres acknowledge this problem. Indeed, their program proposes all sorts of contingency plans for increasing the value of the voucher in both future and pending elections if "voucher turnout" is lower than expected. ${ }^{113}$ These plans, however, are primarily aimed at attaining a certain aggregate value of all vouchers and securing an aggregate voucher-to-private funds ratio. This will not necessarily help individual candidates. Yet some prediction of the likely amount of public funding is crucial for campaign decisions-including the allimportant decision of whether or not to be a candidate. Challengers and political newcomers depend on public funding, and, thus, they need to know how much public money they are likely to get. With flat-grant systems, they know exactly how much they will receive once they qualify for the funding. The uncertainty of funding inherent in a voucher plan may discourage some candidates from entering races and thus diminish electoral competitiveness.

Second, a voucher plan will likely reward early popularity. Early money is critical to an election campaign, particularly for a newcomer or a challenger. The central challenge for such a candidate is getting the attention of the media and the voters. For an unknown candidate, the media challenge likely requires considerable upfront spending. It takes money to build support. But under the voucher plan it takes support to get money. Without some initial public recognition, how will the candidate collect the funds necessary to build support? ${ }^{114}$ Famous candidates, incumbents, or candidates who enjoy the backing of significant political organizations can escape from this Catch-22 and raise the money that will enable them to

113. Id. at 83-90.

114. Ackerman and Ayres are aware of the importanee of early money. They allow a candidate to accept a limited amount of private contributions to an "exploratory committee" that do not pass through the blind trust applicable to all other private contributions. See id. at 206-07. They provide that the first $5 \%$ of all Patriot vouchers available in a House-election cycle, Senate-eleetion cycle, or presidentialelection cycle whieh are aetually transferred to candidates are to be doubled in value. See id. at 211 . This rewards successful early fundraising, but it does not make it any easier and thus might actually help incumbents over challengers. 
mount the campaigns that will enable them to raise more money. For newcomers, challengers, and others without strong start-up financing, however, this is likely to be more difficult. One of the benefits of public funding is that it offsets the advantages of incumbency or celebrity by offering all qualifying candidates substantial upfront funding. Patriot funding throws that possibility away.

Third, although vouchers reflect voter equality, they may fail to promote candidate equality. Flat-grant plans, such as the one now used to fund candidates in the presidential general election, typically assure that major contenders have equal funding. ${ }^{115}$ Although they may discriminate against minor-party challengers, they also reflect the reality that the vast majority of general elections are two-party races. Flat grants boost competition by assuring that the incumbent has a well-financed major party challenger, and that both major parties are able to mount meaningful efforts in all states and districts. Flat grants can greatly increase the number of competitive elections. With the voucher plan, not only is the incumbent or the more famous candidate likely to shoot ahead in fundraising at the start, but there is no guarantee that the candidates will ever be funded equally. In states or districts dominated by one party or a strong incumbent, the challenger may be significantly financially outclassed. Once again, the Ackerman and Ayres plan fails to make use of public funding's potential to level the financial playing field.

Fourth, the voucher plan both diverts a significant portion of public money into fundraising and will require that candidates devote a significant portion of their campaign time and effort to fundraising. With flat-grant public funding, all public dollars come without additional candidate effort once the candidate has qualified. To be sure, fundraising may overlap with campaigning. The target audience for both fundraising and campaigning may turn out to be the same--the entire electorate, or at least that half of the electorate likely to vote-although it is also possible that only a smali subset of voters ordinarily will cast their vouchers. Still, vouchers pressure candidates to shape their campaigns to inelude an express or implicit pitch for money as well as for votes. Patriot money would thus be far less effective than flat grants in promoting electoral competition and reducing the burdens of fundraising.

The differences between the voucher and matching funds programs are less substantial. As with a voucher system, the total amount of public funds a candidate can raise in a matching system is uncertain. Initially popular candidates have an advantage, there is no guarantee of equal funding, and fundraising is still a campaign obligation. Still, matching programs may have the edge over vouchers in some respects, such as helping

115. Some "clean money" systems go further and give all qualifying candidates equal payments. See Ariz. Rev. Stat. $\$ 16-951$. 
newcomers and reducing the burdens of fundraising. In most matching systems, the public matchcs are substantially larger than the $\$ 10, \$ 15$, and $\$ 25$ vouchers in the Patriot plan, so that challengers can use public dollars to more quickly get to the level of funding necessary to mount a meaningful campaign. So, too, less effort will be expended to raise the same amount of money in systems which permit and match donations above the $\$ 25$ level. Moreover, matching systems need not provide simply a dollar-for-dollar match. New York City matches private contributions at a four-to-one ratio up to a ceiling. ${ }^{116}$ This has been a very effective tool for boosting political newcomers and enabling them to get their message before the voters while also reducing the burdens of fundraising. ${ }^{17}$

The operational problems of vouchcrs flow directly from Ackerman and Ayres's vision of campaign funding as a participatory democratic act akin to voting. Although campaigns and their financing are closely intertwined with elections, ${ }^{118}$ the campaign is not the same as the election itself, and a campaign contribution is not the same as a ballot. The election is a distinct moment in time when the entire polity collectively decides who will govern it for the next term of office. That decision comes only after an extendcd period of agenda sctting, issue development, and communications by candidates, parties, political committees, and the media-the period known as the election campaign. During that pcriod of discussion, debatc, and deliberation, views may shift, the relative popularity of competing contenders may reverse, and voters may change their minds. Campaign financing is crucial; it shapes the ability of candidates and other political groups to present their views and counter the views of others. Public funding that gives challengers a substantial upfront grant and assures that the major contenders have similar levels of funding can encourage more candidates and enable newcomers to mount more effective campaigns against incumbents. By contrast, financing that relies heavily on initial popularity runs the risk of reinforcing the initial differences in support and entrenching the early favorites.

Ackerman and Ayres treat the financing of a campaign as an election itself. But that misses the way in which campaign financing is both a dynamic process, in whieh early fundraising success may affect the flow of campaign dollars later, and a critical mechanism for shaping the competition in the election held on election day. Recognizing that a democratic election is predicated on the opportunity for candidates to present their views to and interact with the voters, decentralized campaign financing

116. See New York City Campaign Finance Act, N.Y.C. AdMin. CodE § 3-705 (2002).

117. See, e.g., MARK GREEN, SELLING OUT: HOW BIG CORPORATE MONEY BUYS ELECTIONS, RAMS THROUGH LEGISLATION, AND BETRAYS OUR DEMOCRACY 247-56 (2002).

118. See Issue Advocacy, supra note 4, at 1769 (observing that "[t]he election campaign is a central part of the process of structured choice and democratic deliberation that constitutes an election"). 
through vouchers may be less likely to generate a democratic election than a public financing system that involves a conscious government effort to assure timely and adequate financing for the principal contenders.

The participatory democratic aspect of vouchers may also be overstated. We have no way of knowing how many voters will use their vouchers, particularly in less visible elections like those for the House of Representatives. Assuming that voucher voting is unlikely to exceed election day voting, about half the electorate will cast presidential vouchers and about one-third or so will use Patriot money in congressional elections. ${ }^{119}$ More likely, without the significance of an election day to focus attention on a particular point in time and without the special rituals that have developed concerning election day participation, voucher turnout is likely to be lower than ballot turnout-perhaps just $20-25 \%$ in House of Representatives races. This group may not be a represcntative subsection of the electorate, but may, instead, be skewed in favor of certain groups, such as the more educated or those with more intense political views.

Indeed, political intensity might affect the timing of voucher voting even more than the rate of participation. Voters will almost certainly liken their voucher voting to their ballot voting. Moderates may take more time to make up their minds and may cast their vouchers only as they are getting ready to go to the polls. Their vouchers would be of limited utility for candidates. By contrast, more intense partisans with strongly held views are likely to make up their minds and cast their vouchers early. As a result, not only will voucher usage reflect only a modest fraction of the electorate, but it is likely to favor candidates backed by voters at the ends of the political spectrum rather than the moderates who enjoy more numerous, albeit perhaps less intense, popular support. This would still be far more participatory than the current system, in which only a tiny portion of Americans make campaign contributions, or than a system in which the government makes grants according to a statutory formula. But a system in which the most partisan and ideological fraction of the electorate dominates campaign financing is not exactly a model of democracy.

To be sure, we have no idea how many people will use their vouchers. Ackerman and Ayres contend that Patriot money will energize the electorate to produce high levels of participation and higher levels of political engagement. Indeed, vouchers could enhance election day turnout. To be sure, it is not obvious that the opportunity to spend small amounts of government-provided credits on candidates and political committees would

119. In $2000,51.3 \%$ of the voting age population voted in the presidential general election. Federal Election Commission, Voter Registration and Turnout, http://www.fec.gov/pages/2000turnout/ reg\&to00.htm. Turnout in the 1996 presidential election was just $49.08 \%$ of the voting-age population. See FEC, Voter Registration and Turnout - 1996, http://www.fec.gov/pages/96to.htm. Turnout in the 1998 congressional election was $36.4 \%$ of the voting-age population. See FEC, Voter Registration and Turnout - 1998, http://www.fec.gov/pages/reg\&to98.htm. 
spark a new sense of citizenship. But Ackerman and Ayres might be right, and, if they are, the resulting sense of democratic empowerment might well be more beneficial than the more financially competitive candidacies that government grants would produce. At this point, we just do not know.

Moreover, voucher plans have an undeniable rhetorical appeal. They certainly sound democratic, and they can avoid the "welfare for politicians" label often pinned on public funding since the payments would appear to come from the voters themselves rather than the public treasury. As a result, a voucher plan might garner more public support than other forms of public funding, although in recent years traditional forms of public funding have not done badly at the polls, as the popular referenda adopting public-funding programs in Maine, Massachusetts, Arizona, and San Francisco indicate. ${ }^{120}$ As with the anonymous donation booth, it would be desirable for some states or cities to experiment with voucher plans for state or local elections so we could get a sense of voter utilization and compare the impact on competition with more traditional flat-grant or matching-money systems. Until then, however, given the predictable operational problems that a voucher program would generate, it is difficult to conclude that Patriot money represents an advance over other forms of public funding.

\section{The Mix of Public and Private Funds}

One of the great strengths of the Ackerman and Ayres program is its mix of public and private funds. Although public funding is the cornerstone of their scheme, they would not require candidates to be funded exclusively by public money. Rather, making use of the anonymous donation booth, they would permit candidates to collect and spend private contributions as well as Patriot dollars. Indeed, they would lift the statutory ceiling on private contributions to federal candidates significantly above BCRA's new, expanded levels.

120. See Recent Developments in Campaign Finance Regulation: San Francisco Approves Public Campaign Finance Proposition, Nov. 8, 2000, http:/www.brook.edu/gs/cf/headlines/sf publicCF.htm; Mark Breslow et al, Revitalizing Democracy: Clean Election Reform Shows the Way FORWARD 11 (2002) (noting that Maine voters passed a Clean Election Act by a 56-44 margin in 1996; Arizona voters enacted a similar measure in 1998), http://www.neaction.org/revitalizingdemocracy.pdf; Bates v. Dir. of Office of Campaign \& Political Fin., 763 N.E.2d 6, 9 (Mass. 2002) (noting that Massachusetts Clean Elections Act was "approved overwhelmingly by the people" in November 1998). More recently, in the aftermath of a protracted legislative effort to avoid funding the 1998 Clean Elections Act, Massachusetts votcrs approved a nonbinding resolution, placed on the ballot by the legislature, that they do not "support taxpayer money being used to fund political campaigns for public office." Recent Developments in Campaign Finance Regulation: Massachusetts Voters Support Referendum Rejecting Public Campaign Financing, Nov. 5, 2002, http://www.brook.edu/gs/cf/ publicfin.htm. In the same election, however, a competing referendum which asked voters if they supported "fully implementing and funding" the Clean Election Law was approved in all eleven state House districts in which it was on the ballot. Id. 
On the other hand, Ackerman and Ayres are also committed to assuring that public funds dominate campaign financing. They set the initial value of the voucher at a level high enough to increase campaign spending above current levels and to produce significantly more public funds than private dollars. Their "swamping control" 21 would go further and enable the FEC to increase the value of the Patriot voucher to assure that even if voucher use is lower than anticipated-or private contributions are higher-public money would not be swamped by private dollars but would always constitute at least two-thirds of all campaign money.

Their commitment to a mixed but predominantly public system that would increase, not reduce, campaign funds is absolutely on target. Although some reformers have contended that the one person, one vote principle requires equal dollars per voter, ${ }^{122}$ voter equality is just one of the competing concerns that campaign finance law must reconcile. A campaign finance system should foster the participation of politically engaged citizens in the electoral process and promote a structure of lively electoral competition. As Ackerman and Ayres note, contributions provide an opportunity for participation in the political process. ${ }^{123}$ So long as some mechanism like donor anonymity controls the corrupting effect of large donations while public funding buffers the influence of large donations on electoral competition, there is no reason to bar private money. Moreover, private contributions can also foster electoral competition and the presentation of opposing viewpoints to the electorate. Any public-funding system must have a means of determining which candidates qualify for funding. Past voter turnout may havc limited relevance to the current election. Opinion poll data may lack legitimacy. In addition, those approaches tend to favor those candidates or partics who start out ahead and make it difficult for challengers, minor parties, and independents to break into the system. A system permitting some private funding enables thcsc contenders to launch their candidacies by using their initially small but intense private support to build the base necessary to take on an incumbent or other favored candidate, and to qualify for public funding. ${ }^{124}$

Ackerman and Ayres's commitment to increasing the pool of campaign money over current levels is cqually important. Too often, support for campaign finance reform is driven by the sense that there is too much money in politics and that campaign spending is too high. But that is simply mistaken. Campaign spending is a tiny fraction-about five-hundredths of one percent-of gross domestic product, and well under what

121. ACKERMAN \& AYREs, supra note 21 , at 89.

122. See, e.g., Edward B. Foley, Equal-Dollars-Per-Voter: A Constitutional Principle of Campaign Finance, 94 Colum. L. Rev. 1204 (1994).

123. See ACrerman \& Ayres, supra note 21, at 33-34.

124. Id. at $36,58-60$. 
Americans spend on potato chips. ${ }^{125}$ If anything, not enough money is being spent to inform and motivate voters and to create competitive races. The problem is not too much money but the private sources of funding (and the attendant corruption danger) and the maldistribution of eampaign money in favor of incumbents. Rather than using the occasion of the adoption of a public-funding system as an opportunity to cut spending, as some reforms have done, ${ }^{126}$ Ackerman and Ayres would appropriately increase the overall level of funding. Other public funding reformers should follow their lead in seeking to use public funding to increase overall funding as well as to include mechanisms, like the aforementioned swamping control, that assure that public funds predominate over, rather than merely supplement, private contributions.

III

Reform OR Regulatory Revolution: VOTING WITH DOLLARS AS A NEW Paradigm For Campaign Finance?

Both anonymous donations and the voucher form of public funding are distinctly innovative approaches to the basic problems of campaign finance. ${ }^{127}$ Ackerman and Ayres work out the operational elements of these concepts and provide a detailed statutory text for implementing their ideas. They also address and propose model legislation concerning other aspects of campaign finance, particularly the structure of the FEC. Not content with being merely innovative and thorough rcformers, Ackerman and Ayres want to be something more-regulatory revolutionaries. In putting forward their program, from their book's subtitle on down, they repeatedly stress how their proposals constitute a "new paradigm" that reflects the "regulatory revolution of the past generation." 128 They stress that the planks of the traditional campaign finance reform platform- "[c]ommand and control, bureaucratic subsidies, and full information [-] are part of the

\footnotetext{
125. SмITH, supra note 54 , at 42.
}

126. For example, when Congress adopted presidential public funding in 1974, it set the baseline grant to major party candidates at $\$ 20$ million-or one-third of the campaign spending by Richard Nixon just two years earlier and, more strikingly, only two-thirds of the $\$ 30$ million spent by the candidate who in 1972 suffered the worst defcat of any major party candidate in modern times, George McGovern. The presidential election grant, which rises with the cost of living, did not reach the amount in nominal dollars Nixon had spent in 1972 until 1996, or a quarter century later. See Public Funding, supra note 16 , at 586 .

127. For an earlier elaboration and defense of the voucher concept, see Richard L. Hasen, Clipping Coupons for Democracy: An Egalitarian/Public Choice Defense of Campaign Finance Vouchers, 84 Calif. L. Rev. 1 (1996). Professor Hasen's proposal followed a magazine article by Professor Ackerman proposing that vouchers be used as the mechanism for providing public funding. See id. at 21 n.89; Bruce Ackerman, Crediting the Voters: A New Beginning for Campaign Finance, 13 AM. PRospect 71 (1993). Although Professor Hasen provided a thorough theoretical defense of using vouchers, he did not work out the details of a voucher plan, as Professors Ackerman and Ayres, with Mr. Berubé, did.

128. See ACKERman \& AYres, supra note 21, at 3. 
problem, not part of the solution." 22 By "command and control," they refer to FECA's limitations on the amounts and sources of contributions and expenditures. They clearly announce that their goal is "to distance [themselves] from ... the great progressive goal" of "limit[ing] the amount of private money flowing into campaigns." 130 They "reject comprehensive controls on private money" 131 ; in their view, anonymity can do the work of regulatory controls. "Bureaucratic subsidies" are, of course, flat- or matching-grant forms of public funding. Indeed, they blast traditional publicfunding systems as "centralized bureaucratic solutions"132 in which "bureaucrats give politicians handouts." 133

It all sounds impressively revolutionary. Yet, the central tenets of their claim to being revolutionary-the rejection of both command-andcontrol regulation and a bureaucratized public-funding system-are belied by the provisions of their program. Innovative as their proposal is, it is also marked by powerful continuities with more traditional features of campaign finance reform.

Thus, despite their rhetorical pounding of contribution restrictions, Ackerman and Ayres would continue virtually every single contribution restriction in federal elections currently on the books. Specifically, they would restrict individual contributions to candidates, political parties, and nonparty political committees, as well as limit the aggregate annual amount any individual can contribute to federal candidates, parties, and political organizations. ${ }^{134}$ They would also continue the longstanding prohibitions on campaign contributions by corporations and labor unions. ${ }^{135}$ Indeed, they would go further than current law by barring PACs from contributing private dollars to candidates, ${ }^{136}$ barring national political parties from transferring funds to state and local parties, ${ }^{137}$ and restricting not just the total amount an individual could give a candidate during the campaign as a whole but also the amount the donor can give during any two-week period during an election year or four-week period in a nonelection year. ${ }^{138}$ So, too, while they repeatedly criticize the regulatory loophole-closing focus of Senators McCain and Feingold, ${ }^{139}$ Ackerman and Ayres devote considerable attention to "plugging the gaps" and writing regulatory rules that

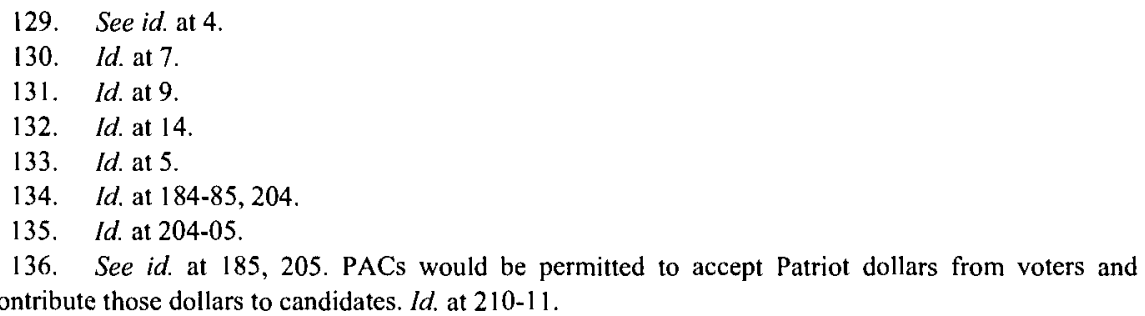

137. Id. at 185 .

138. Id. at 203.

139. See, e.g., id. at 7-8, 45-46, 119-20. 
would preclude donor or candidate evasion of the blind trust requirement and their contribution limits. ${ }^{140}$ Indeed, they copy precisely one element of the McCain-Feingold approach to soft money by extending the blind trust regulation to all contributions to the national parties. ${ }^{141}$ As they note, with the blind trust device, like FECA's contribution limits, "ongoing regulatory work [is] required to proteet the integrity of the system." 142

To be sure, Ackerman and Ayres would generally raise the contribution limits well above even the increased levels that just took effect under BCRA. ${ }^{143}$ They would also vary the limits according to the office in question-representative, senator, or president-resulting in dramatically higher limits on donations to presidential candidates than under present law. ${ }^{144}$ In their system, the regulatory center of gravity would shift, with the bulk of the work of controlling the corrupting effects of contributions borne by the anonymity rule, not the contribution limits, although the combination of the continuing ban on eorporate and union contributions and the new ban on corporate and union PAC private contributions suggests that these command-and-control rules would still be doing a fair amount of work. The contribution limits and prohibitions would be "regulations of last resort," 45 not front-line defenses as they are currently. Yet, given the plethora of new and continuing restrictions - not to mention the commandand-control directive to contribute solely through the blind trust donation booth - this seems less a revolutionary paradigm shift and more a reform within the existing model of contribution restrietions and information regulation.

Similarly, Ackerman and Ayres frame their ease for voter vouchers over grants to candidates in rhetoric that blasts grant programs as bureaucratic while exalting Patriot money as decentralizing and democratic. Ackerman and Ayres, however, overstate the role of the much-maligned bureaucracy in traditional public funding while they understate the powers of the bureaucracy under the Patriot plan.

In traditional flat-grant or money-matching systems, the bureaucracy has the relatively limited role of determining whether a candidate has met the statutory criteria to qualify for funding, the amount of contributions the candidate has obtained, and whether the candidate complies with the other terms and conditions of the program. The key questions-who gets public money and how much they get-are determined not by the bureaucracy but by statutory formulas adopted by the elected representatives or, in states and localities that have enacted public funding by ballot initiative, by the

140. See id. at $123-26$.

141. Id. at 203.

142. Id. at 126.

143. Id. at 203-04.

144. Id.

145. Id. at 45 . 
people themselves. Decisions made by elected representatives may not be decentralized, but they are certainly democratic. Decisions made by voter initiatives are both decentralized and democratic-or at least as decentralized and democratic as decisions of voters casting Patriot dollars.

While bureaucracy plays only a minor role in determining who gets how much money under traditional public funding, the FEC could actually play a largc role in determining how much money candidates receive under the Patriot system. The FEC would not simply carry out the commands of the Patriot money statute. Instead, the model statute gives the agency authority to vary the value of the Patriot vouchers to assure that election funding does not fall below a certain level and that public funds outpace private funds by a two-to-one ratio. ${ }^{146}$ Moreover, during the first eight years of the program, the FEC would have the authority to adopt regulations increasing the value of Patriot vouchers during a current election to assure that the overall level of funding is maintained. ${ }^{147}$ Finally, in determining both the overall amount of campaign money and the public-toprivate funds ratio, the FEC "may develop"148 regulations that would include in the calculation of private money not just contributions to candidates through the blind trust but "private eommunication" broadly defined to include expenditures for what would currently be considered issue advocacy. ${ }^{149}$

Given the FEC's powers to alter the value of Patriot accounts and its considerable discretion to determine the amount of private money in an election, it is difficult to say that the bureaucracy will not have a role to play in the Patriot system. Indeed, the bureaucracy would probably have much more power than in other public-funding systems. That is not necessarily a criticism; but it is inconsistent with the bureaucracy bashing that is part of the Ackerman and Ayres case for Patriot money. ${ }^{150}$

146. Id. at 218-19.

147. See id. at 219 .

148. Id. at 220 .

149. See id. at 187.

150. My focus on the bureaucracy's role in the Ackerman and Ayres plan ignores their many legislative rules and requirements intended to shape the value of vouchers and the benefits to eandidates. Thus, although Ackerman and Ayres begin by presenting their plan as one whieh gives every eligiblc voter fifty Patriot dollars, they quickly move to constrain voter discretion by allocating $\$ 10$ to House races, $\$ 15$ to Senate races, and $\$ 25$ to presidential races, and by then subdividing the presidential account into $\$ 10$ for the primary campaign and $\$ 15$ for the general election campaign. See id. at 4, 9. But the subdivision of the presidential amount would only occur in years when the incumbent President is a candidate for re-election. Sce id. at 209. Ackerman and Ayres also double the value of the first $5 \%$ of the funds available in House, Senate, and presidential elections, respectively, as an incentive to early Patriot donations. See id. at 211 . These are all reasonable rules, but they belie the claim that the Patriot plan decentralizes decisions to the voters. 


\section{CONCLUSION}

Ackerman and Ayres have presented a comprehensive plan that, by combining bold innovations with meticulous attention to detail, addresses the central issue of campaign finance: how to provide candidates with the money they need for informing and communicating with voters without also making elected officeholders dependent on special interests and wealthy donors. By joining the anonymous donation booth and high contribution limits to public funding, they would largely sever the tie between private wealth and public elections. And they would do so by increasing, not reducing, the amount of money available for campaign communications.

I have been critical of various components of the Ackerman and Ayres program, and of some of the rhetoric that goes with it. It is not clear that contribution anonymity is superior to disclosure. Vouchers are likely to be less effective than government grants in promoting competitive elections. Although Ackerman and Ayres are right in seeking to make campaign financing more congruent with the democratic norm of voter equality, they push the dollars-as-votes analogy too far. Campaign contributions can affect electoral outcomes, but they are not votes. Rather, they are part of the process of shaping the electoral debate, informing voters, and presenting the personalitics and views of the candidates to the electorate. On the continuum strctching between general political activity and election day voting, they are somewhere in between-closer perhaps to balloting than to the general discussion of political issues, but still distinct from the election itself. By relying on the dollars-voting analogy to insist on individual voter allocation of public funds to candidates, they lessen the ability of public funding to level the playing field between challengers and incumbents and to promote competitive contests. So, too, in modeling the "donation booth" on the voting booth, they run the risk of denying voters potentially significant information about candidates' issue-motivated financial backers-although they make a good case that anonymity (if maintained) would effectively curb access-oriented contributions.

Still, whatever the arguable shortcomings of the individual elements of the Ackerman and Ayres program, the whole is greater than the sum of the parts. Overall, their proposal represents a reasonable and pragmatic reconciliation of the multiple and conflicting concerns-protection of political speech and association, voter equality, electoral competitiveness, and checking the undue influence of large donors-central to campaign finance regulation. If I had to choose between their program and the status quo on a take-it-or-leave-it basis, I would pick their plan in a heartbeat. 
Moreover, as they point out, the principal proposals in Voting with Dollars would all be constitutional under existing doctrine. ${ }^{151}$ Buckley $v$. Valeo is often considered to be an immovable object blocking the path to reform, ${ }^{152}$ but Ackerman and Ayres have demonstrated that far-reaching reforms that would both promote democratic equality and check the corrupting influence of large private donations are entirely consistent with Buckley. In developing and working through a creative and comprehensive campaign reform program, Ackerman and Ayres have demonstrated that the obstacles to campaign finance reform are more political than constitutional.

Voting with Dollars arrives at a critical time. The decade-long campaign against soft money and issue-advocacy advertising has culminated in a fragile victory which, if it survives eourt challenges and is vigorously enforced-admittedly two very big ifs-opens the way to political consideration of the next phase of reform: the provision of no-strings-attached funds to candidates. Indeed, if BCRA is knocked out by the courts or eviscerated by the $\mathrm{FEC}^{153}$ and very large contributions continue to flow without regulation or restraint, the need to find new means of providing candidates adequate no-strings-attached funding will be even more pressing. Ackerman and Ayres have presented a plan that addresses that need in a comprehensive and operationally detailed manner. Their book should stimulate and advance public debate over this matter, which is so vitally important to the health of our democracy. That alone is a noteworthy achievement.

151. On the other hand, some of their other proposals-the ban on PAC contributions of private dollars to candidates, the regulation of all contributions to national political parties, and the control on the timing and pace as well as the amount of individual private contributions to candidates-are more constitutionally debatable.

152. ACKERMAN \& AYRES, supra note 21, at 140-59.

153. The FEC has already taken steps to undermine BCRA's soft-moncy ban. See Richard Briffault, The Future of Reform: Campaign Finance After the Bipartisan Campaign Reform Act of 2002, 34 ARIZ. ST. L.J. 1179, 1205-08 (2002). For critical commentary on the FEC's soft-money rules, see Stop Opening Loopholes, WASH. Post, June 22, 2002, at A18; Election Law Coup d'Etat, N.Y. T1MES, June 24, 2002, at A18 